\title{
Preclinical models of acute liver failure - a comprehensive review
}

\author{
Joshua Hefler ${ }^{\text {Corresp., } 1}$, Braulio A. Marfil-Garza ${ }^{1,2,3}$, Rena L. Pawlick ${ }^{1}$, Darren H. Freed ${ }^{4}$, Constantine J. Karvellas ${ }^{5,6}$, \\ David L. Bigam ${ }^{1}$, A.M. James Shapiro ${ }^{\text {Corresp. 1,7 }}$ \\ ${ }^{1}$ Division of General Surgery, Department of Surgery, Faculty of Medicine \& Dentistry, University of Alberta, Edmonton, Alberta, Canada \\ 2 National Institutes of Medical Sciences \& Nutrition Salvador Zubiran, Mexico City, Mexico \\ 3 CHRISTUS-LatAm Hub Excellence \& Innovation Center, Monterrey, Mexico \\ 4 Division of Cardiac Surgery, Department of Surgery, Faculty of Medicine \& Dentistry, University of Alberta, Edmonton, Alberta, Canada \\ 5 Division of Gastroenterology, Department of Medicine, Faculty of Medicine \& Dentistry, University of Alberta, Edmonton, Alberta, Canada \\ 6 Department of Critical Care Medicine, Faculty of Medicine \& Dentistry, University of Alberta, Edmonton, Alberta, Canada \\ 7 Clinical Islet Transplant Program, University of Alberta, Edmonton, Alberta, Canada \\ Corresponding Authors: Joshua Hefler, A.M. James Shapiro \\ Email address: hefler@ualberta.ca, jshapiro@ualberta.ca
}

Acute liver failure is marked by the rapid deterioration of liver function in a previously well patient over period of days to weeks. Though relatively rare, it is associated with high morbidity and mortality. This makes it a challenging disease to study clinically, necessitating reliance on preclinical models as means to explore pathophysiology and novel therapies. Preclinical models of acute liver failure are artificial by nature, and generally fall into one of three categories: surgical, pharmacologic or immunogenic. This article reviews preclinical models of acute liver failure and considers their relevance in modeling clinical disease. 
1 Title: Preclinical Models of Acute Liver Failure - A Comprehensive Review

2

3 Authors: Joshua Hefler ${ }^{1}$, Braulio A. Marfil-Garza ${ }^{1,2,3}$, Rena Pawlick ${ }^{1}$, Darren H. Freed ${ }^{4}$,

4 Constantine J. Karvellas ${ }^{5,6}$, David L. Bigam ${ }^{1}$, A.M. James Shapiro ${ }^{1,7 *}$

6 Authors Addresses:

$71^{1}$ Division of General Surgery, Department of Surgery, Faculty of Medicine \& Dentistry,

8 University of Alberta, Edmonton, Canada

$9{ }^{2}$ National Institutes of Medical Sciences \& Nutrition Salvador Zubiran, Mexico City, Mexico

$10{ }^{3}$ CHRISTUS-LatAm Hub Excellence \& Innovation Center, Monterrey, Mexico

$11^{4}$ Division of Cardiac Surgery, Department of Surgery, Faculty of Medicine \& Dentistry,

12 University of Alberta, Edmonton, Canada

135 Division of Gastroenterology, Department of Medicine, Faculty of Medicine \& Dentistry,

14 University of Alberta, Edmonton, Canada

$15{ }^{6}$ Department of Critical Care Medicine, Faculty of Medicine \& Dentistry, University of Alberta,

16 Edmonton, Canada

$17{ }^{7}$ Clinical Islet Transplant Program, University of Alberta, Edmonton, Canada

$20 *$ Corresponding author

21 A.M. James Shapiro ${ }^{1,7}$

22 1-002 Li Ka Shing Centre for Health Research Innovation, Edmonton, AB T6G 2E1

23 E-mail address: jshapiro@ualberta.ca (AMJS) 


\section{Abstract}

25 Acute liver failure is marked by the rapid deterioration of liver function in a previously well patient over period of days to weeks. Though relatively rare, it is associated with high morbidity and mortality. This makes it a challenging disease to study clinically, necessitating reliance on preclinical models as means to explore pathophysiology and novel therapies. Preclinical models of acute liver failure are artificial by nature, and generally fall into one of three categories: surgical, pharmacologic or immunogenic. This article reviews preclinical models of acute liver failure and considers their relevance in modeling clinical disease.

\section{Introduction}

Acute liver failure (ALF) refers to the rapid deterioration of liver function in an individual without pre-existing liver disease within 26 weeks (O'Grady, Schlam \& Williams, 1993). ALF is a challenging disease to study clinically due to its relative rarity and high mortality. Annual cases

37 in the US are estimated to be in the range of 2,000 to 3,000 (Stravitz \& Lee, 2019). A report of 1,147 cases by the US ALF study group found an overall mortality of 30\% (Lee et al., 2008). Animal models are important for the study of such rare diseases, both for understanding pathophysiology and for development of potential treatments, as the lack of access to patients and 41 severity of their illness makes clinical studies challenging.

The main considerations with using laboratory animals to model human disease are their appropriateness and generalizability. Animals that are closer to humans evolutionarily are considered more generalizable. However, rodent models, though less comparable to humans than some large animal models (e.g., pigs and non-human primates) are more prevalent for economic, ethical and logistic reasons. 
47 Broadly, artificially-induced preclinical ALF models can be grouped into surgical, 48 pharmacological or immunogenic approaches (Table 1). Common techniques used in surgical 49 models include total hepatectomy, major liver resection, temporary hepatic ischemia, and a 50 combination of portacaval shunting with hepatic artery ligation (Argibay et al., 1996; de Groot et

51 al., 1987; Makino et al., 2005; Yamaguchi et al., 1989). A range of pharmacological models have 52 also been studied. Among the most widely used are acetaminophen (APAP), d-galactosamine (d53 Gal), and carbon tetrachloride $\left(\mathrm{CCl}_{4}\right)$ (Apte, 2014; Frank et al., 2020; Mossanen \& Tacke, 2015)

54 (Table 2). Immunogenic models refer to models of viral hepatitis, as well as means of inducing 55 hepatitis by activating cell death pathways, such as with anti-Fas antibodies (Bajt et al., 2000; Belz, 2004). There are additional models for specific etiologies of ALF that fall outside of these categories, such as the Long Evans Cinnamon rat, which models ALF in the context of abnormal copper metabolism, similar to Wilson's disease seen in humans (Siaj et al., 2012).

This review provides an overview and summary of animal models of ALF reported in the literature to date, including a discussion of technical aspects. Our aim is to bring together these divergent approaches and expertise into a single resource. We hope that it will be useful to researchers new to the field, as well as those more experienced seeking to explore alternative 63 approaches.

Survey Methodology

A literature search was conducted of PubMed, MedLine and Web of Science using the search terms "acute liver failure" and "fulminant liver failure". Clinical studies were excluded from the search results. There was no restriction based on language. Models categorized by their method of inducing liver failure and representative articles were chosen for inclusion. Older literature reviews 
70 on the same topic were consulted to ensure key topics were not missed (Rahman \& Hodgson, 2000;

71 Filiponi \& Mosca, 2001; Bélanger \& Butterworth, 2005)

73 Defining ALF

transaminases) with acute onset of hepatic encephalopathy (HE) and synthetic liver dysfunction,

marked by elevated international normalized ratio (INR; typically $\geq 1.5$ ), in a previously well individual without pre-existing liver disease (Stravitz \& Lee, 2019). The timeline for the development of ALF is less than 26 weeks (Stravitz \& Lee, 2019). However, ALF may be subdivided into hyperacute ( $<7$ days), acute ( 7 to 21 days), and subacute ( 21 days to 26 weeks) (Stravitz \& Lee, 2019).

Definitions of ALF in animal models are less precise (Fig. 1). The main criterion is often simply elevation of transaminases. Coagulopathy is not often assessed, especially in small animals, where blood volume is prohibitive and other pathophysiological aspects are usually being investigated concomitantly. There are scoring systems for HE, even in small animals, but these are often only reported when HE is the focus of the study (Butterworth et al., 2009). In contrast to the clinical presentation, where tissue biopsies are not routinely taken, histology takes greater emphasis in animal studies, as it can demonstrate the expected findings of hepatic necrosis (Mitchell et al., 1973a). Lethality is also often reported as evidence of sufficient injury, though current animal ethical guidelines counsel strongly against survivability or death as a primary study endpoint (Wang et al., 2000).

The timeline for ALF in animal models is shorter than in humans. Generally, in studies 
93 This can be justified as the inciting event is known, whereas clinically (except in cases of acute

94 overdose) patients may present with progressive worsening over days and weeks. Laboratory

95 animals also have shorter lifespans. For instance, the median lifespan of laboratory mice is 28

96 months, so applying the clinical definition of 26 weeks would represent over $20 \%$ of the animal's

97 life. Additionally, most aspects of rodent biology, including metabolic rate, and RNA and protein

98 turnover, are several times that of humans (Agoston, 2017). This is especially true for more

99 complex biological processes. For instance, in rodent models of chronic liver injury, fibrosis

100 develops in as little as 4 weeks, whereas cirrhosis in humans takes years (Schuppan \& Afdhal,

101 2008; Yanguas et al., 2016).

102 In actuality, the majority of animal models purported to represent ALF may correspond more

103 closely with acute liver injury (ALI) (Koch et al., 2017). Clinically, ALI is a less precisely defined

104 term, generally referring to elevated transaminases, possibly with synthetic dysfunction, but

105 without acute HE. Still, both exist on the same spectrum of injury, with ALF at the more severe

106 end, and it is reasonable to expect that treatments effective against ALI would also work against

107 ALF by the same cause (though perhaps to a lesser degree).

108

109 Animal Selection

110 Animal models of ALF are uniformly mammalian. Though other liver diseases have been

111 studied in lower vertebrates, they are less suitable to model complex clinical syndromes, such as

112 ALF. The most common animals used are mice and rats, which have obvious economic and logistic

113 advantages. However, rodents can differ from animals with closer evolutionary relationships to

114 humans, particularly with regards to inflammatory and metabolic responses (Seok et al., 2013).

115 For instance, hepatic metabolism by cytochrome P450 (CYP450) in humans has been shown to 
116 more closely resembles dogs than rats (Nishimuta et al., 2013). This concern is not unique to

117 animal models of ALF. There are many examples of therapies that work well in rodents, but failed

118 to be translatable to humans. A systematic review including 76 highly-cited ( $>500$ citations)

119 animal studies found that only $37 \%$ were replicated in clinical trials (Hackam \& Redelmeier, 120 2006).

121 Pigs have emerged as the large animal model of choice for liver disease. They share 122 anatomical and physiologic similarities to humans and are a more socially acceptable alternative 123 to dogs or non-human primates, as well as being more accessible than primates. Rabbits have a 124 specific role for the study of viral hepatitis, as there exists a viral disease specific to rabbits (i.e., 125 rabbit haemorrhagic disease) that is characterized by acute necrotizing hepatitis and is typically 126 fatal within 72 hours (Abrantes et al., 2012). Small primate models, such as mouse lemurs, are 127 being considered by some as a way to maximize the ratio between fidelity and cost, but have not 128 yet been adapted to the study of ALF (Ezran et al., 2017).

129 Humanized models, in which immunodeficient mice are engrafted with human cells or 130 tissues, are being used increasingly, particularly in pharmacologic and immunologic studies (Allen 131 et al., 2019). In the case of mice with humanized liver, human hepatocytes are transplanted into 132 immunodeficient mice, resulting in the replacement of over $70 \%$ of the native mouse liver (Strom, 133 Davila \& Grompe, 2010). There are reports of these mice being used to study ALF. Torres et al. 134 (2019) described a model of APAP-induced ALF in mice with humanized livers, but found that 135 the mice were less susceptible to hepatotoxicity than their wildtype counterparts. This may reflect

136 the importance of other factors, such as an appropriate immune response, in producing the full 137 syndrome of ALF. 
In addition to species considerations, several criteria have been proposed for ideal animal

139 models of ALF. The first and most recognized were put forth by Terblanche and Hickman (1991).

140 Among these, they emphasized the importance of reversibility (i.e., that a treatment intervention

141 could lead to survival), reproducibility (often judged by the following criteria), consequent death

142 (from liver failure and not secondary causes), and a therapeutic window for intervention

143 (necessitated by the first criteria). Consciousness has also been suggested to be important for

144 assessment of HE, but may not be possible for ethical reasons (Bélanger \& Butterworth, 2005).

\section{Surgical Models of ALF}

147 Some surgical models, such as portacaval anastomosis (PCA) with hepatic artery ligation

148 and partial hepatectomy with ischemia or portacaval shunt, seek to create a generalized model of

149 ALF, whereas other surgical models are aimed at specific causes of ALF (e.g., post-hepatectomy

150 or ischemia).

151 Anhepatic Models

152 Anhepatic models have been described in rats, rabbits, dogs, and pigs (Joyeux et al., 1977;

153 Yamaguchi et al., 1989; Nyberg et al., 1993; Frühauf et al. 2004). Both single and multi-stage

154 procedures have been reported. With the former, it is necessary to reconstitute flow between the

155 infrahepatic inferior vena cava (IVC) and the portal vein, caudally, and the suprahepatic IVC

156 cranially. This can be done using a simple shunt or anastomosis with a prosthetic graft (e.g.,

157 polyethylene terephthalate or polytetrafluoroethylene) (Arkadopoulos et al., 1998; Filipponi et al.,

158 1999; Frühauf et al. 2004). Multi-stage procedures were developed specifically for use in rats. A

159 two-stage procedure was described by Rozga et al. (1992). In the first stage, atrophy of the

160 posterior lobes (right and caudate lobes) is induced by ligation of posterior portal branches. After 
161 two weeks, in the second stage, the hypertrophied anterior lobes (median and left lobes) are

162 resected, a portacaval anastomosis is created, and the hepatic artery is ligated (fully

163 devascularizing the atrophied posterior lobes). The atrophy of the posterior lobes, which are

164 normally adherent to the IVC, obviates the need for vena cavo-caval anastomosis. This reduces

165 technical complexity and associated mortality, which can be significant in small animal models.

166 Three-stage techniques have also been described earlier in the literature, in which ligation of the

167 IVC above the renal veins is carried out in the first stage (Holmin, Alinder \& Herlin, 1982). Two

168 months later, after adequate collateral circulation has developed, a portacaval anastomosis and

169 total hepatectomy are carried out in separate operations.

170 While anhepatic models produce the purest form of liver failure in some sense, they lack a

171 direct clinical correlate. The only time a patient is without a liver is in the anhepatic phase between

172 hepatectomy and graft implantation during a liver transplantation, which typically lasts for little

173 over an hour (IJtsma et al., 2009). While absence in the liver's synthetic function is readily

174 apparent in such models, they lack features of systemic dysfunction (e.g., acidemia, elevated

175 lactate) that accompany clinical cases of ALF, caused by hepatocyte death.

176 Anhepatic models also lack reversibility. They have been used in metabolic studies, as well

177 as studies of HE. They are unsuitable for most therapeutic studies, though may provide an

178 advantage in studies of extracorporeal liver support (e.g., bioartificial livers [BALs]) due to the

179 consistency of absolute hepatic insufficiency. Because of the lack of systemic dysfunction, they

180 do have a longer survival time. In a direct comparison between models, Frühauf et al. (2004) found

181 an average survival time of 17.1 hours in an anhepatic porcine model, compared to 9.8 hours in a

182 devascularized model.

183 Partial Hepatectomy 
An alternative to total hepatectomy are major liver resection models, which generally range

185

186

187

188

189

190

191

192

193

194

196

197

from $70 \%$ to $95 \%$ resection of the liver mass. The lower end corresponds to the $20-30 \%$ recommended to avoid post-operative liver failure after hepatic resection of an otherwise healthy liver (Guglielmi et al., 2012). This has been reported in mice, rats, rabbits, pigs, and baboons.

The rodent liver has four lobes: right, median, left, and caudate (Rogers \& Dintzis, 2018).

Nomenclature is expectedly imprecise, particularly in older literature. Both the right and caudate lobes have two distinct segments, which are nearly bisected by a transverse septum. The two segments of the right lobe may be labeled superior and inferior or anterior and posterior. The caudate lobe has also been referred to as the omental lobe. In some studies, the inferior segment of the right lobe is referred to as the caudate lobe, while what is otherwise known as the caudate lobe is referred to as the quadrate lobe and papillary process (Longo et al., 2005; Abe et al., 2009). The median lobe of the rat is reliably bilobed and may be referred to separately as right and left median lobes (usually with the descriptor 'lateral' added to the right and left lobes) (Rogers \& Dintzis, 2018). Notable differences between the mouse and rat livers are the relatively larger size of the left lobe in the former and the lack of a gallbladder in the latter (Fig. 2).

Livers of other commonly used experimental animals are similarly lobulated (Vons et al., 2009; Nykonenko, Vávra \& Zonča, 2017; Stan, 2018). Nomenclature used is also similar to rodents. The livers of rabbits, dogs, and pigs are generally described as having six lobes (Budras et al., 2007; Swindle, 2016; Stan, 2018). In these animals, the equivalent of the median lobe is divided into distinct right and left lobes and a small quadrate lobe is found inferior to them, to which the gallbladder is partially attached. Right and left lateral and caudate lobes appear in a similar position as rodents. Studies on the surgical anatomy of the liver in non-human primates is limited. A detailed study in the cynomolgus monkey (Macaca fasciularis) described four lobes as 
207 in rodents (Vons et al., 2009). Despite differences in external appearance, the same internal

208 segmentation is consistent between species (Kogure et al., 1999; Nykonenko, Vávra \& Zonča, 209 2017).

210 In both the mouse and rat, resection of the median and left lobes is generally referred to as

$21170 \%$ hepatectomy (sometimes 2/3), while 90\% hepatectomy adds resection of the right lobe

212 (Bustos et al., 2003; Makino et al., 2005). Some studies report more precise percentages based on

213 measured volumes, which may vary slightly between species and strains (Inderbitzin et al., 2006;

214 Lehmann et al., 2012). Alternative approaches describe sparing only the superior or inferior

215 segment of the right lobe (variably reported as 80-87\% hepatectomy) (Ogata et al., 2008; Ohashi

216 et al., 2013). A 95\% hepatectomy has also been described, which includes resection of all lobes

217 except the inferior segment of the caudate, and even a 97\% hepatectomy where all lobes are

218 resected and the only pericaval hepatic tissue (at the base of the resected lobes) remains

219 (Madrahimov et al., 2006). Resection in rodents is best achieved by ligating portal structures

220 separately, rather than together with hepatic parenchyma, as this avoids venous outflow

221 obstruction (Makino et al., 2005). Figure 3 illustrates the different degrees of hepatic resection

222 employed in models of ALF following partial hepatectomy.

223 Though $70 \%$ hepatectomy has been described by some studies as a model of ALF, it may be

224 more suitable for regenerative studies of partial hepatectomy. A study in mice found 100\% survival

225 at one week following 70\% hepatectomy, whereas $90 \%$ hepatectomized mice all died within 24

226 hours (Makino et al., 2005). Evidence of regeneration was also seen by 10 hours in the 70\% group,

227 but not in the $90 \%$ group. A similar study in rats likewise found improved hepatocyte regeneration

228 in rats with $70 \%$ compared to $90 \%$ hepatectomy (Meier et al., 2016). $90 \%$ hepatectomized rats 
229 also showed evidence of coagulopathy and higher elevation in transaminases more consistent with 230 ALF.

231 Pagano et al. (2012) found that more extensive hepatic resection was required to produce

232 liver failure in pigs. Even with resection of left lateral, left and right median, and half of the right 233 lateral lobe ( $\sim 80 \%$ hepatectomy), only $65 \%$ of the animals in their study developed liver failure,

234 whereas none of the animals with lesser resections did. 90\% hepatectomy models have also been 235 reported in rabbits, pigs and baboons (Berlinger et al., 1987; Asencio et al., 2017; Navarro-Alvarez 236 et al, 2018). As in rodents, these models are based on resection of all lobes except for the caudate.

237 Variations of major liver resection models have also been described. These can be used to 238 emphasize a particular aspect of ALF that may be lacking or at least less apparent in models of 239 partial hepatectomy alone. A model of $70 \%$ hepatectomy plus ischemia to remnant or right lobe 240 only has been described in rats, rabbits, pigs, and baboons (Eguchi et al., 1996; Hung et al., 2007;

241 Arkadopoulos et al., 2011; Machaidze et al., 2017). The addition of ischemia induces liver necrosis

242 in the remnant lobes, which is otherwise lacking from models of partial hepatectomy alone. This

243 adds a systemic inflammatory response that more closely parallels many clinical cases of ALF.

244 The addition of common bile duct (CBD) ligation to partial hepatectomy has been also described

245 as a means of reliably inducing jaundice, though this is obstructive and not hepatocellular in nature

246 (Moharib et al., 2014). Likewise, PCA has been added to reliably induce HE, which may be absent

247 or at least not readily apparent in animal models of partial hepatectomy, especially given the briefer 248 course of disease in comparison to clinical cases (Filipponi et al., 1991). A less commonly used 249 model, reported by Baimakhanov et al. (2016), employed a combination of partial hepatectomy 250 and radiation-induced liver damage (50Gy) to the remaining lobes. The addition of radiation 251 inhibits proliferation of remaining hepatocytes. 
252

253

254

255

256

257

258

259

260

261

262

263

264

265

266

267

268

269

270

271

272

273

274

\section{Portocaval Anastomosis \& Hepatic Artery Ligation}

Another commonly used surgical model involved PCA plus hepatic artery ligation. This has

been described in rats, rabbits, dogs, and pigs, though not in mice, presumably because it is made more impracticable by their size (Fick, Schalm \& de Vlieger, 1987; Bonato et al., 1989; Ash et al., 1993; Argibay et al., 1996). PCA may be done at the same time as arterial ligation or separately.

The two-stage procedure is used to reduce mortality and typically consists of the portacaval anastomosis, followed by hepatic artery ligation 48 to 72 hours later. The second stage may alternatively be done by placing slings around the hepatic artery and bile duct at the first operation, which are then exteriorized and later tied off to induce global liver ischemia (Khalili et al., 2001). Portacaval shunting alone (sometimes referred to as an Eck fistula) has been used to study HE, but is insufficient to fully model ALF (Starzl, Porter \& Francavilla, 1983). As with total hepatectomy models, PCA and hepatic artery ligation result in irreversible loss of entire liver function. However, leaving the liver in situ adds physiological effect of hepatic necrosis seen clinically. As with total hepatectomy models, these models of complete devascularization are not reversible, but have utility in the study of HE or assessment of BALs.

To add reversibility, models of temporary ischemia have been described in dogs, and pigs (Horák, Horký \& Ruzbarský, 1980; de Groot et al., 1987). In pigs, temporary ischemia of 4 to 14 hours in duration by occlusion of the hepatic artery has been reported, with or without occlusion of the CBD, following PCA. De Groot et al. (1987) reported 50\% mortality and $15-67 \%$ hepatic necrosis with 4-hour occlusion compared to $85 \%$ mortality and $49-75 \%$ necrosis with 6 hours of ischemia. Fourneau et al. (2000) tested increasing ischemic times from 6 to 14 hours and found $100 \%$ mortality in 5 animals subjected to 10 hours of ischemia, with occlusion of the CBD. Animals without CBD occlusion, however, were able to survive up to 14 hours of ischemia. 


\section{Pharmacological Models of ALF}

277 Acetaminophen

278 Acetaminophen (APAP) is a commonly used pharmacological model. This reflects the fact 279 that it is the most prevalent cause of ALF in North America clinically and is readily available as 280 an over-the-counter medication (Rubin et al., 2018). The mechanism of APAP toxicity has been 281 well studied. Briefly, toxicity occurs when excessive doses of APAP cause metabolism through a 282 secondary pathway mediated by the CYP450 family of enzymes. This pathway produces the 283 hepatotoxic metabolite, N-acetyl-p-benzoquinone imine (NAPQI), which is thought to induce 284 toxicity chiefly through formation of mitochondrial protein adducts and generation of reactive 285 oxygen species (Ramachandran \& Jaeschke, 2019). Glutathione (GSH) is an antioxidant molecule 286 found in nearly all eukaryote cells, which is capable of detoxifying NAPQI. This is the principle 287 upon which treatment with N-acetylcysteine (NAC) is based. NAC is hydrolyzed to cysteine in 288 cells, providing the rate-limiting substrate necessary for GSH synthesis (Heard, 2008).

Reduction of GSH stores by approximately $80 \%$ is necessary for hepatotoxicity to occur 290 (Mitchell et al., 1973a). Sensitizing agents have been employed to this end. One of the most 291 commonly employed is phenobarbital, which works by inducing CYP450 (Miller et al., 1976). 292 Another CYP450 inducer, 20-methylcholanthrene (20-MC), has also been reported to be effective 293 (Rahman, Selden \& Hodgson, 2002). An alternative strategy is inhibition of GSH synthase, such 294 as with buthionine sulfoximine (BSO), which has been shown to decrease GSH stores to $15-20 \%$ 295 when given at $2 \mathrm{mg} / \mathrm{kg}$ two hours prior to APAP administration in mice (Kelly et al., 1992).

296 APAP toxicity models have been described in mice, rabbits, dogs, and pigs (Francavilla et 297 al., 1989; Rahman, Selden \& Hodgson, 2002; Newsome et al., 2010; Mossanen \& Tacke, 2015). 
298 It can be administered intravenously (IV), intraperitoneally (IP), subcutaneously (SC), or orally

299 (PO). IP is preferred for mice, whereas IV or SC is more commonly used for large animal models.

300 PO reflects what is seen clinically, but has the disadvantage in animal models of slower onset and

301 more variable absorption. Though an IV formulation exists for human use, the aqueous solubility

302 of APAP is suitable for animal experiments, where prolonged storage is not required, with most

303 protocols using normal saline (NS) or phosphate buffered saline (PBS) as the diluent prior to

304 administration (Chiam et al., 2018). Less commonly, the prodrug of APAP, propacetamol, can be

305 used at twice the dose (Tsai et al., 2015). The animal is typically fasted overnight prior to

306 administration, regardless of whether anesthesia is used, as this is reasoned to ensure comparable

307 levels of GSH between animals (Vogt \& Richie, 1993). Because of the depletion in GSH that

308 results, fasting also serves to exacerbate hepatotoxicity caused by APAP (Walker et al., 1982).

309 The relative resistance of rats to APAP-induced hepatotoxicity has been described in early

310 literature (Mitchell et al., 1973b). McGill et al. (2012) compared mechanisms of APAP-toxicity

311 directly between mice and rats. They found less depletion of GSH in rats, despite higher doses

$312(1 \mathrm{~g} / \mathrm{kg}$ vs. $300 \mathrm{mg} / \mathrm{kg} \mathrm{IP})$, and concluded that this was the result of lower rates of mitochondrial

313 protein binding. Despite this, several studies report the use of rats as an APAP-toxicity model with

314 doses ranging from $400 \mathrm{mg} / \mathrm{kg}$ IP to $5 \mathrm{~g} / \mathrm{kg}$ PO (Panatto et al., 2011; Mahmoud et al., 2016). The

315 lower toxicity of APAP in rats may be offset by combining it with other forms of acute (partial

316 hepatectomy) or chronic (non-alcoholic steatohepatitis) hepatic injury (Kučera et al., 2012; Sahay

317 et al., 2019).

318 Mice are the most common animal model used for APAP-induced ALF. Doses range from

$319200-900 \mathrm{mg} / \mathrm{kg} \mathrm{IP}$, given as a single bolus. PO is less commonly used, though dosing is similar, as

320 APAP bioavailability of enteral APAP is close to $90 \%$, with several studies using $300 \mathrm{mg} / \mathrm{kg}$ 
321 (McGill et al., 2012). Most studies using higher doses ( $\geq 500 \mathrm{mg} / \mathrm{kg})$ report mortality $>90 \%$ within

32248 to 72 hours. Lv et al. (2019) found 95\% mortality at 48 hours using a dose of 900mg/kg.

323 Several studies have directly compared different doses. Barman et al. (2016) found all mice

324 (C57 BL/6 §̂, aged 8-10 weeks) survived to 5 days with a dose of $200 \mathrm{mg} / \mathrm{kg}$, whereas only $75 \%$

325 survived with the $350 \mathrm{mg} / \mathrm{kg}$ dose, and all mice given $400 \mathrm{mg} / \mathrm{kg}$ died within 80 hours. Serum

326 transaminases and histology were consistent with ALF at the highest dose, with levels of alanine

327 aminotransferase (ALT) greater than 5,000 U/L and close to 50\% necrosis at 12 hours. Ham et al.

328 (2015) using essentially the same strain of mice (C57 BL/6 $\curvearrowright$, aged 9-10 weeks) found 100\%

329 survival at 3 days with $400 \mathrm{mg} / \mathrm{kg}, 70 \%$ survival with $500 \mathrm{mg} / \mathrm{kg}$, and $100 \%$ mortality with

$330600 \mathrm{mg} / \mathrm{kg}$. Transaminase levels were reported at 48 hours, so were considerably lower (just under

$331600 \mathrm{U} / \mathrm{L}$ ). Shen et al. (2018) compared 3 doses of APAP (again using male C57 BL/6 mice) and

332 found similar levels of serum transaminases at 24 hours with 300 and $500 \mathrm{mg} / \mathrm{kg}$ doses $(>5,000$

$333 \mathrm{U} / \mathrm{L}$ ). However, $180 \mathrm{mg} / \mathrm{kg}$ produced only minor increases. Monitoring levels at various time

334 points, they found that serum transaminases peaked at 6 hours post injection and remained elevated

335 at similar levels up to 24 hours. By 48 hours, levels had returned to normal.

336 Another important factor in these models is the use of the same sex. Studies tend to use male

337 mice, as females have been found to be less susceptible to APAP-induced hepatotoxicity (Du et

338 al., 2014). Pharmaceutical CYP450 induction or GSH depletion may be used, but is not required

339 in mice and appears less frequently in the literature compared to other animal models. GSH

340 depletion by overnight fasting is frequently employed.

341 Rabbits are less widely used compared to mice. Rahman et al. (2002) developed a model

342 consisting of five doses of $500 \mathrm{mg} / \mathrm{kg}$ SC over 24 hours. Both GSH depletion with BSO and 
343 CYP450 induction with 20-MC were found to be necessary to achieve hepatic necrosis. However,

344 they were not successful using phenobarbital with BSO or BSO alone with these doses of APAP.

345 While mouse models are not typically anesthetized, modern protocols using large animal

346 models maintain sedation for the duration of the experiment to avoid undue suffering to the animal

347 and allow for invasive monitoring. An early study by Henne-Bruns et al. (1988) described the

348 challenges of developing a porcine model. They reported that at lower doses $(500-1,000 \mathrm{mg} / \mathrm{kg})$,

349 though hepatocyte necrosis was seen on histology, all animals recovered, whereas higher doses

$350(1,000-2,000 \mathrm{mg} / \mathrm{kg})$ resulted in rapid death due to methemoglobinemia. Gazzard et al. (1975)

351 found a similar problem in canines. Methemoglobin levels exceeded $40 \%$ in animals given 0.75

352 and $1 \mathrm{~g} / \mathrm{kg} \mathrm{IP.} \mathrm{Given} \mathrm{PO} \mathrm{at} \mathrm{doses} \mathrm{of} 1 \mathrm{~g} / \mathrm{kg}$ all animals died, but only two-thirds showed elevated

353 transaminases and only one had evidence of hepatic necrosis on autopsy.

354 Treatment of methemoglobinemia, such as with methylene blue, has not been used to address

355 this problem. Instead, most large animal models have moved to using continuous or multiple doses

356 of APAP. Francavilla et al. (1989) succeeded in developing a reproducible canine model, using

$357750 \mathrm{mg} / \mathrm{kg} \mathrm{SC}$, followed by two doses of $200 \mathrm{mg} / \mathrm{kg}$ at 9 and 24 hours. However, it has not been

358 replicated in recent literature, as dogs have largely fallen out of favor as a large animal model.

359 Two porcine models of APAP toxicity have emerged in the current literature. Newsome et

360 al. (2010) describe a model in which APAP is administered IV. Animals were pretreated with

$36120 \mathrm{mg}$ of phenobarbital for 5 days prior to the experiment. On the day of study, pigs were bolused

362 with $0.1875 \mathrm{~g} / \mathrm{kg}$ of APAP, followed by a 12 -hour infusion of $1.8 \mathrm{mg} / \mathrm{kg} / \mathrm{min}$, adjusted to achieve a

363 blood APAP concentration between 200 and 300mg/L. Experiments lasted up to 28 hours, with 2

364 of the 9 treated animals surviving, 5 dying of multiorgan failure or sepsis, and 2 succumbing to

365 respiratory failure induced by methemoglobinemia. Aspartate aminotransferase (AST) levels 
366 reached the several hundreds, and factors V and VII showed a significant decrease, though

367 increased intracranial pressure (ICP) was not seen. Animals developed varying degrees of necrosis,

368 with 6 showing at least moderately severe liver injury and 3 having only mild injury. Of note, the

369 point of care (POC) assay used in this study to maintain the APAP levels has been shown to be

370 unreliable and is no longer commercially available (Egleston et al., 1997). We were unable to find

371 any quantitative POC tests for APAP on the market today.

372 A second porcine model of APAP-induced ALF has been described by Thiel et al. (2011).

373 In their study, APAP was administered via nasojejunal tube, first as a $250 \mathrm{mg} / \mathrm{kg}$ bolus, then 1-

$3743 \mathrm{~g} / \mathrm{hr}$ to maintain APAP plasma levels between 300-450mg/L until ALF was achieved (as judged

375 by impaired coagulation). The method of APAP measurement was not reported. They found $100 \%$

376 mortality by 30 hours (no control group was provided for comparison). AST levels rose into the

377 several hundreds and coagulopathy was demonstrated, with an average INR of 5.7 by the end of

378 the study. They also reported ICP elevated to $>30 \mathrm{mmHg}$. Expected findings of centrilobular

379 necrosis were confirmed on histology. Both porcine models required maintenance under anesthesia

380 and continuous monitoring, as well as adjustment of APAP levels, which makes these models

381 expensive and challenging to reproduce.

382 Yu et al. (2015) attempted to develop a primate model of APAP toxicity in M. fasicularis,

383 but found the animal to be resistant to hepatotoxicity up to doses of $900 \mathrm{mg} / \mathrm{kg}$ per day for 14 days.

384 Only minor, sporadic increases in liver transaminases were seen in the macaques, despite achieving

385 a blood concentration 3.5 times that associated with liver toxicity in humans.

D-Galactosamine

D-galactosamine (d-Gal) is another commonly used pharmacological agent for inducing

388 ALF in animal models. D-Gal is an amino sugar derived from galactose, otherwise found as a 
389

390 follicle stimulating hormone (Apte, 2014). It causes toxicity by depleting intracellular stores of

391 uridine - a necessary component of RNA synthesis - through metabolism in the Leloir pathway,

392 which results in the accumulation of UDP-galactosamine. This also deprives the cell of uridine

393 derivatives, UDP-glucose and UDP-galactose, necessary for glycogen synthesis. It has further

394 been shown to activate Kupffer cells, leading to the release of proinflammatory cytokines and 395

neutrophil infiltration (Yang et al., 2016). D-Gal characteristically results in diffuse rather than zonal necrosis seen with most hepatotoxic drugs.

D-Gal may be given with or without lipopolysaccharide (LPS; sometimes referred to as endotoxin), a component of the outer membrane of Gram-negative bacteria, which exacerbates the immune-mediated liver injury (Hamesch et al., 2015). Recognized as a pathogen-associated molecular pattern, LPS triggers a massive release of inflammatory cytokines. In mice, pretreatment with LPS has been shown to ameliorate this effect, though it is not clear that this would be the case in humans, as our susceptibility to LPS is several magnitudes higher than rodents (Zhang et al., 2014). Common sources of LPS include Escherichia coli, Pseudomonas aeruginosa, and Salmonella enterica. Biological activity can vary based on bacterial source and supplier, so preliminary testing may be necessary prior to proceeding with the full model (Hamesch et al., 2015).

LPS has been used on its own to induce ALF in rodents, but requires bacterial inoculation, commonly with Cutibacterium acnes (formerly Propionibacterium acnes), to achieve full effect (Brodsky et al., 2009). It has been observed that LPS enhances acute and chronic infections in mice, particularly resulting in bacterial infiltration into the liver (Hamesch et al., 2015). LPS has 
411 also been combined with partial hepatectomy in rats to produce a surgical model of ALF with an

412 inflammatory component (Skawran et al., 2003).

413 D-Gal dosed at $400-1,000 \mathrm{mg} / \mathrm{kg}$ when given alone or at $300-700 \mathrm{mg} / \mathrm{kg}$ when given with

$4140.1 \mathrm{mg} / \mathrm{kg}$ of LPS has been shown to consistently induce ALF in rodents (Apte, 2014). Higher

415 doses, up to $3 \mathrm{~g} / \mathrm{kg}$, have been used in some studies, particularly in those investigating HE, as doses

416 in this range will render rats comatose within 36 to 48 hours and cause $>90 \%$ mortality within 72

417 hours (Birraux et al., 1998). Slower onset HE can be achieved using multiple small doses over a

418 period of weeks. For instance, Ganai and Husain (2018) administered 250mg/kg via IP injection

419 biweekly to achieve HE in 30 days.

420 Galun et al. (2000) tested escalating doses in male Fischer rats from 100 to $500 \mathrm{mg} / \mathrm{kg}$,

421 looking for a sub-lethal model of ALF. They found that doses greater that $300 \mathrm{mg} / \mathrm{kg}$ resulted in 422 significant elevation in ALT $(>1,500 \mathrm{U} / \mathrm{L})$, as well as a sharp decline in the activity of coagulation 423 factors V and VII. In female rats, doses greater than $300 \mathrm{mg} / \mathrm{kg}$ uniformly resulted in death, whereas 424 in male rats, doses of at least $1 \mathrm{~g} / \mathrm{kg}$ were required to ensure $100 \%$ mortality by 5 days. In a study 425 using male Wistar rats, Cauli et al. (2008) found that a dose of $2.5 \mathrm{~g} / \mathrm{kg}$ IP resulted in $100 \%$ 426 mortality in an average time of 24.5 hours, whereas a $1.5 \mathrm{~g} / \mathrm{kg}$ dose had only $77 \%$ mortality at 7 427 days, with an average time to death of 48 hours.

428 The majority of rodent studies use both d-Gal and LPS, particularly in mice. The dose of 429 LPS varied from study to study, ranging from 1-500 $\mu \mathrm{g} / \mathrm{kg}$ (Zhang et al., 2011; Liu et al., 2019). It 430 is difficult to judge from existing studies whether LPS has a dose-dependent effect when 431 administered with d-Gal or whether a certain minimal amount is required, as this has not been 432 investigated directly. Separate studies using different doses of LPS report comparable levels of 433 liver injury. For instance, Chen et al. (2012) reported serum AST and ALT levels close to 2000U/L 
434 and $80 \%$ mortality within 12 hours in an ALF model administering $800 \mathrm{mg} / \mathrm{kg}$ d-Gal and $20 \mu \mathrm{g} / \mathrm{kg}$

435 LPS to BALB/c mice. Takamura et al. (2007) similarly reported serum ALT of nearly 2,000U/L 436 and AST of $1,500 \mathrm{U} / \mathrm{L}$ in BALB/c mice, as well as $80 \%$ mortality within 12 hours using the same 437 does of d-Gal, but with $100 \mu \mathrm{g} / \mathrm{kg}$ of LPS. The LPS used in these studies was purchased from the 438 same manufacturer, but the bacterial species of origin is not reported, highlighting an additional 439 challenge in interpreting these studies in relation to LPS. Tumour necrosis factor $\alpha(\mathrm{TNF} \alpha)$ has 440 also been used in combination with d-Gal, instead of LPS. Wang et al. (2018) found similar peak 441 transaminases $(>7,500 \mathrm{U} / \mathrm{L})$ in mice comparing d-Gal administered with either $5 \mu \mathrm{g} / \mathrm{kg}$ of LPS or $44210 \mu \mathrm{g} / \mathrm{kg}$ of TNF $\alpha$, though the peak occurred later (6h vs. 9h) in mice receiving TNF $\alpha$.

443 D-Gal has also been used in other animal models of ALF, including rabbits, dogs, pigs, and 444 monkeys (Ferenci et al., 1984; Sielaff et al., 1995; Kalpana et al., 1999). Most of the studies using 445 rabbits reported doses in millimoles, ranging from $3.25-5.1 \mathrm{mmol} / \mathrm{kg}$ (equivalent to $582-914 \mathrm{mg} / \mathrm{kg}$ ) 446 (Ferenci et al., 1984; Jauregui et al., 1995). Not all of the parameters of ALF were reported in these 447 studies, but they were successful at inducing hepatic coma at these doses. Wang et al. (2000) 448 administered doses as high as $1.2 \mathrm{~g} / \mathrm{kg}$ to rabbits for the purpose of testing a bioartificial liver 449 (BAL), at which they demonstrated uniform lethality, elevated transaminases into the several 450 thousands, and extensive hepatic necrosis.

451 Canine studies have used doses of d-Gal alone ranging from $0.5-2 \mathrm{~g} / \mathrm{kg}$ to induce ALF 452 (Sielaff et al., 1995; Nyberg, Cerra \& Gruetter, 1998). Though, some studies have reported that 453 doses greater than $1.5 \mathrm{~g} / \mathrm{kg}$ are necessary to induce sufficient hepatic injury. For instance, Nyberg, 454 Cerra \& Gruetter (1998) found that doses of 1.7 and $2 \mathrm{~g} / \mathrm{kg}$ resulted in dramatic elevations in AST $455(>4,000 \mathrm{U} / \mathrm{L}), \mathrm{INR}(>10)$, and intracranial pressure ( $>3 \mathrm{x}$ baseline), whereas the lower dose of $1 \mathrm{~g} / \mathrm{kg}$ 456 produced comparatively mild liver injury, with AST of 287U/L and INR of 1.5. Using a dose of 
$4570.5 \mathrm{~g} / \mathrm{kg}$ in beagles, Zhang et al. (2012) reported a rise in serum transaminases to nearly 1,000U/L,

458 tripling of prothrombin time (PT), and doubling serum ammonia after 24 hours, consistent with

459 the clinical definition. Insufficient detail was provided in these studies to assess whether these

460 differences could be due to breed, age or other factors.

461 Similar doses have been reported in porcine studies, ranging from 0.3 to $1.5 \mathrm{~g} / \mathrm{kg}$ (Cao et al.,

462 2012; Sang et al., 2016). Ho et al. (2002) compared 0.5 and $1 \mathrm{~g} / \mathrm{kg}$ doses and found that both

463 resulted in manifestations of ALF (including elevated transaminases, coagulopathy, and severe

464 hepatic necrosis), though the animals receiving the lower dose survived longer. Several studies

465 using the higher dose of $1.5 \mathrm{~g} / \mathrm{kg}$ reported similar mean survival times, ranging from 3 to 4 days,

466 and elevations in AST of several thousand (Cao et al., 2012; Li et al., 2012; Shi et al., 2017). Li et

467 al. (2012) additionally reported significant coagulopathy, with a PT more than 6x normal, and 468 hyperammonemia, close to $150 \mu \mathrm{mol} / \mathrm{L}$ by the third day.

469 Feng et al. (2017) compared several doses of d-Gal in M. fascicularis $-0.3 \mathrm{~g} / \mathrm{kg}, 0.25 \mathrm{~g} / \mathrm{kg}$, and $4700.2 \mathrm{~g} / \mathrm{kg}$. The lowest dose did not result in biochemical or physiologic changes consistent with 471 ALF, though animals did experience elevated transaminases into the several hundreds. Both of the 472 higher doses produced similar elevations in transaminases $(>1,000 \mathrm{U} / \mathrm{L}), \mathrm{PT}$, and ICP, among other 473 measures. The animals receiving the highest dose, however, had a shorter survival time and more 474 extensive necrosis on pathology.

475 Carbon Tetrachloride

476 Though more commonly used in chronic models of hepatic fibrosis, carbon tetrachloride $477\left(\mathrm{CCl}_{4}\right)$ can be given in a single large dose to induce acute injury. Hepatic fibrosis is achieved by 478 administering multiple small doses. Particularly in small animals (e.g., rodents), this can be 479 achieved on a timescale ( 2 to 4 weeks) that would fit into the clinical definition of ALF in humans. 
480 However, it is not clear that this represents the same disease process and is likely more reflective

481 of a chronic injury, especially given shorter animal lifespans (as discussed above).

$482 \mathrm{CCl}_{4}$ is activated by one of several members of CYP450 enzymes to produce a 483 trichloromethyl radical $\left(\mathrm{CCl}_{3}{ }^{*}\right)$, which binds with a variety of macromolecules (nucleic acids, 484 proteins, lipids), disrupting vital intracellular processes (Weber, Boll \& Stampfl, 2003). $\mathrm{CCl}_{3}{ }^{*}$ can 485 be further oxidized, creating a highly reactive trichloromethylperoxy radical $\left(\mathrm{CCl}_{3} \mathrm{OO}^{*}\right)$. This 486 molecule is particularly reactive with phospholipids and triglycerides (Boll et al., 2001). Lipid 487 peroxidation of the membrane lipids destroys the integrity of cell and organelle membranes, 488 resulting in permeabilization and loss of ion gradients. Reactive aldehydes produced from 489 oxidative degradation of fatty acids bind to functional groups of proteins, inhibiting enzymatic 490 function. It is unclear whether any single injury pattern predominates. More likely, it is the cascade 491 of multiple insults unleashed by $\mathrm{CCl}_{4}$ that culminates in cell death.

$492 \quad \mathrm{CCl}_{4}$ has been used to create models of ALF in rodents, as well as rabbits and pigs (Choi \& 493 Burm, 2005; Nardo et al., 2008; Frank et al., 2020). Rodent studies typically use doses ranging 494 from 0.5 to $2.5 \mathrm{ml} / \mathrm{kg}$ administered IP or PO (via gavage). Similar doses are used for mice and rats. 495 Gastrointestinal absorption is known to be rapid, though this is somewhat impaired after dilution 496 in oil (e.g., corn, olive), a common vehicle used for either route (Kim et al., 1990). Frank et al. 497 (2020) tested doses of $0.5,1.25$, and $2.5 \mathrm{ml} / \mathrm{kg}$ (absolute $\mathrm{CCl}_{4}$ volume) administered orally to male 498 Sprague Dawley rats. All doses produced elevation of serum transaminases into the several 499 thousands after 24 hours and high grade tissue injury on histology, though the effect was greater 500 with higher doses. Mark et al. (2010) found a similar dose dependant effect on survival of female

$501 \mathrm{C} 57 \mathrm{BL} / 6$ mice after administering $1,1.5,2$, and $2.25 \mathrm{ml} / \mathrm{kg}$. The two highest doses resulted in $502100 \%$ mortality by 5 days, compared to $60 \%$ and $80 \%$ mortality for the lowest. 
A rabbit model of $\mathrm{CCl}_{4}$-induced $\mathrm{ALF}$ has been reported by some studies, though is not well

504 characterized. A representative study by Choi and Burm (2005) administered escalating SC doses

505 of $\mathrm{CCl}_{4}$ to achieve varying degrees of hepatic injury in white male New Zealand rabbits. The

506 lowest tested dose, $0.5 \mathrm{ml} / \mathrm{kg}$, resulted in only mild increases in serum transaminases. Doubling the

507 dose to $1 \mathrm{ml} / \mathrm{kg}$ resulted in increased transaminases to the several hundreds. Only the highest tested

508 dose, $2 \mathrm{ml} / \mathrm{kg}$, produced transaminases in a range consistent with ALF, with an ALT of 552U/L

509 and an AST of 1,476U/L. The absence of additional parameters (e.g., INR, serum ammonia) and

510 survival data make it difficult to judge if this model is truly representative of ALF.

511 Several studies using a porcine model of acute $\mathrm{CCl}_{4}$-induced hepatotoxicity have also been

512 described. Nardo et al. (2008) administered $\mathrm{CCl}_{4}$ at a dose of $0.45 \mathrm{mg} / \mathrm{kg}$ IP, which resulted in

513 elevated transaminases $(>1,000 \mathrm{U} / \mathrm{L})$, and decreased PT to $34 \%$ of normal at 24 hours. These

514 animals had $100 \%$ mortality at 48 hours.

515 Some porcine models have combined surgery and $\mathrm{CCl}_{4}$ administration. An early model 516 described by Alp and Hickman (1987) involved occlusion of the hepatic artery for 2 hours prior to 517 IP injection of $0.5 \mathrm{mg} / \mathrm{kg}$. The development of ALF was evidenced by serum biochemistry, 518 including an AST in the several thousand, elevated serum ammonia more than 8x normal, and a 519 PT decreased to $32 \%$ of normal. Yuasa et al. (2008) described a laparoscopic approach, involving 520 ligation of all hepatic arterial branches, and direct intra-portal injection of $\mathrm{CCl}_{4}$, followed by portal 521 vein occlusion for 30 minutes. They tested three doses $-5,7.5$, and $10 \mathrm{~mL}-$ in $25 \mathrm{~kg}$ pigs and 522 concluded the middle dose caused injury suitable for an ALF model, whereas the lower dose led 523 to eventual recovery and the higher dose precipitated rapid demise.

\section{Thioacetamide}


Thioacetamide is an organosulfur compound, which, like $\mathrm{CCl}_{4}$, can be used in both acute

526 and chronic models of liver injury. In the liver, it undergoes a two-step activation, first to

527 thioacetamide-S-oxide (TASO), then to thioacetamide-S,S-dioxide $\left(\mathrm{TASO}_{2}\right)$, which is mediated

528 by either CYP450 enzymes or flavin adenine dinucleotide-containing monooxygenase (Hajovsky

529 et al., 2012). Both metabolites have cytotoxic effects. TASO has been shown to inhibit

530 mitochondrial activity and alter cell membrane permeability, leading to nuclear enlargement and

531 increased intracellular $\mathrm{Ca}^{2+}$ concentration (Akhtar \& Sheikh, 2013). $\mathrm{TASO}_{2}$ binds and forms

532 acetylimidolysine with multiple proteins, leading to their denaturation. This causes dysregulation

533 of multiple cellular processes, including mitochondrial respiration, the endoplasmic reticular

534 transport system, and heat shock proteins (Akhtar \& Sheikh, 2013).

535 The majority of ALF models using thioacetamide have been reported in rodents.

536 Thioacetamide is typically administered by IP injection in acute models, as opposed to chronic

537 models, where it may alternatively be given PO. For acute models, thioacetamide is typically

538 dissolved in NS or PBS and may be given as a single dose $(200-1,600 \mathrm{mg} / \mathrm{kg})$ or as multiple daily

539 doses $(200-600 \mathrm{mg} / \mathrm{kg} / \mathrm{d})$ for two to four days (Wallace et al., 2015). It has been particularly well

540 characterized as a rodent model of HE. Strain-specific differences in the development of hepatic

541 fibrosis in chronic models using thioacetamide has been noted, though this has not been well

542 studied in acute models (Wallace et al., 2015).

543 Miranda et al. (2010) reported a study testing single doses of 200, 600, and $1200 \mathrm{mg} / \mathrm{kg}$ in

544 male C57 BL/6 mice. They found no significant difference in neurological assessment between

545 the $200 \mathrm{mg} / \mathrm{kg}$ dose and controls. Though they did not report additional measures for this dose, at

$546600 \mathrm{mg} / \mathrm{kg}$ serum ALT was elevated over 1,500U/L at 24 hours and histology showed evidence of

547 periacinar hemorrhagic necrosis. At the highest dose, mortality was significantly increased, 
548 reaching $75 \%$ at 50 hours, compared to $33 \%$ with $600 \mathrm{mg} / \mathrm{kg}$. Similarly, Koblihová et al. (2014)

549 tested single doses of $175,262.5$, and $350 \mathrm{mg} / \mathrm{kg}$ in male rats, both Lewis and Wistar stains. They

550 found the Wistar rats to be more susceptible to death compared to the Lewis rats, with even the

551 smallest dose resulting in a steady drop in survival after 48 hours, increasing in a dose-dependent

552 fashion. In contrast, Wistar rats had higher peak ALT ( 700-1,000U/L), with little appreciable

553 difference between doses for both strains. Peak plasma ammonia, though elevated from baseline,

554 appeared to decrease with increasing thioacetamide, though this was not compared directly.

555 Histology of rats administered the $350 \mathrm{mg} / \mathrm{kg}$ dose of both strains confirmed expected findings of

556 hemorrhagic necrosis involving mainly perivenular zones.

557 Studies comparing single versus multiple doses tend to be somewhat confounded by the

558 differential timing of measurements, but nonetheless show increased level of injury (in both serum

559 biochemistry and histology) and more profound HE, as would be expected with repeat dosing

560 (Mladenović et al., 2012; El Khiat et al., 2019). A unique finding that has been reported in several

561 studies is the susceptibility of streptozosin-treated diabetic rats to thioacetamide, such that one-

562 tenth of a dose produces the same degree of injury in diabetic as non-diabetic rats (30 vs.

$563300 \mathrm{mg} / \mathrm{kg})($ Sawant et al., 2006).

564 Azoxymethane

565 Azoxymethane is a compound that was originally isolated from cycad palm nuts (Cycas

566 circinalis) and has been widely used in animal models of colorectal cancer, where it induces

567 tumour formation via DNA alkylation (Laqueur et al., 1963; Fiala et al., 1991). While hepatic

568 metabolism of azoxymethane into methylazoxymethanol is key to its carcinogenicity, the specific

569 mechanism of its hepatoxicity has not been clearly elucidated. It has been shown to cause oxidative

570 stress, at least in colonic epithelial cells, by decreasing activity of antioxidant enzymes and 
571 depleting intracellular GSH (Waly et al., 2014). It is also known to cause lipid peroxidation, which

572 can disrupt membrane integrity (Waly et al., 2016).

573 With respect to ALF, azoxymethane has predominantly been studied in mouse models. As

574 with thioacetamide, azoxymethane is often employed for the study of HE. Commonly used doses

575 are 50 or $100 \mathrm{mg} / \mathrm{kg}$, diluted in NS or PBS and administered via IP injection.

576 The use of azoxymethane to induce ALF in mice was first described by Matkowskyj et al.

577 (1999) in a study of male C57 BL/6s. They reported that a 100mg/kg resulted in decline in activity

578 within 6 hours, followed by rapid progression through all stages of HE, ending with hepatic coma

579 and death within 41 hours. This was associated with a dramatic elevation in serum ALT, peaking

580 at $12,231 \mathrm{U} / \mathrm{L}$ by 36 hours. Histology showed hemorrhagic centrilobular necrosis with eventual

581 obliteration of hepatic veins.

582 Many rodent models of ALF neglect to demonstrate coagulopathy, which is a key component

583 of the clinical diagnosis. However, this has been explicitly studied in azoxymethane-induced liver

584 failure. Doering et al. (2002) reported ( $\widehat{C} \mathrm{C} 57 \mathrm{BL} / 6$ mice) reduction of factor $\mathrm{V}$ and factor VII

585 activity to $2.4 \%$ and $10.1 \%$, respectively, by 48 hours after $30 \mathrm{mg} / \mathrm{kg}$ of azoxymethane. $50 \mathrm{mg} / \mathrm{kg}$

586 caused even more dramatic reduction to less than $2 \%$ by 36 hours. In this study, all mice receiving

58730 or $50 \mathrm{mg} / \mathrm{kg}$ eventually progressed to hepatic coma and death, in an average of 45 and 33 hours

588 respectively, whereas mice receiving a lower dose of $15 \mathrm{mg} / \mathrm{kg}$ failed to develop $\mathrm{HE}$ and survived 589 to 72 hours.

590 Other Pharmacological Agents for Inducing ALF in Animal Models

591 Toxic mushrooms belonging to the genus Amanita have been well documented to cause ALF

592 in humans, though estimated to be responsible for $<1 \%$ of cases (Karvellas et al., 2016). The

593 specific toxin, $\alpha$-amanitin, is a cyclic peptide, 8 amino acids in length (Santi et al., 2012). A- 
594 amanitin is an inhibitor of RNA polymerase II, and so disproportionately affects organs with high

595 rates of protein synthesis, such as the liver (Karvellas et al., 2016). It is readily absorbed by

596 hepatocytes on first pass metabolism, and though $\sim 60 \%$ secreted in bile, it is returned to liver via

597 enterohepatic circulation. It has also been shown to cause damage to kidneys, pancreas, adrenals 598 and testes.

599 A-amanitin has been used as a means to induce ALF in mouse, pig, and rhesus macaque 600 models (Takada et al., 2001; Zhou et al., 2012; Jedicke et al., 2014). However, experience with $\alpha$ 601 amanitin-induced ALF in mice is limited. The available studies have used doses of $0.6 \mathrm{mg} / \mathrm{kg}$ and 602 show 100\% mortality within 72 hours and histologic evidence of necrosis (Jedicke et al., 2014; 603 Ferriero et al., 2018).

604 Large animal models have been successful in achieving ALF using a combination of $\alpha$ 605 amanitin and LPS. Two porcine studies describe $0.1 \mathrm{mg} / \mathrm{kg}$ of $\alpha$-amanitin and $1.0 \mu \mathrm{g} / \mathrm{kg}$ of LPS, 606 administered directly into the portal circulation (Takada et al., 2001; Ishiguro et al., 2003). In 607 comparison to animals treated with $\alpha$-amanitin alone, Takada et al. (2001) found that co608 administration with LPS resulted in all animals succumbing to hepatic coma and death within 5 609 days, whereas in the other group three of the four animals survived to 7 days and experienced 610 normalization of ICP. Likewise, AST in the $\alpha$-amanitin only group peaked at less than 1,500U/L, 611 compared to $>9,000 \mathrm{U} / \mathrm{L}$ with the addition of LPS. Histology also showed severe centrilobular 612 hemorrhagic necrosis with combined treatment.

613 Two studies have been published describing ALF in a M. mulatta model, induced via $\alpha-$ 614 amanitin and LPS (Zhou et al., 2012; Li et al., 2018). Both used 0.1mg/kg of $\alpha$-amanitin and $6151.0 \mu \mathrm{g} / \mathrm{kg}$ of LPS IP and both reported similar results, consistent with ALF. Serum ALT and AST 616 rose to over 4,000 and $8,000 \mathrm{U} / \mathrm{L}$, respectively, PT peaked at 300s, and all untreated animals 
617 progressed rapidly to hepatic coma and death within 72 hours. Histology correspondingly showed 618 extensive hemorrhagic necrosis.

619 A-naphthyl isothiocyanate (ANIT) has also been used in models of ALF. As opposed to the 620 other drugs mentioned, ANIT is characterized by cholestatic injury (Dahm, Ganey \& Roth, 2010). 621 ANIT forms conjugates with GSH, which are transported into the biliary system by multidrug 622 resistance-associated protein 2 (MRP2). Subsequent dissociation from GSH leads to high 623 concentrations of ANIT in cholangiocytes. Injury to cholangiocytes results in impaired bile flow 624 and intrahepatic accumulation of bile acids, progressing to hepatocyte necrosis.

625 Shen et al. (2020) use $100 \mathrm{mg} / \mathrm{kg}$ PO to induce ALF in male Sprague-Dawley rats. This 626 resulted in elevations of ALT and AST in the range of 600-750U/L and 750-1,050U/L respectively. 627 Other studies in rats have reported similar findings, including the development of focal areas of 628 necrosis on histology (Yang et al., 2017). Though ANIT has yet to be fully characterized as a 629 model of ALF, it has potential for further development based on its unique mechanism of acute 630 cholestatic liver injury.

631 Cocaine toxicity is a rare cause of ALF in humans, reported in literature only as individual 632 cases (Kanel et al., 1990). The mechanism has been suggested to be related to metabolites of 633 norcorcaine, itself a secondary metabolite of cocaine, which results from N-demethylation by 634 CYP450 in $\sim 10 \%$ of the drug (Kanel et al., 1990). Specifically, the norcocaine nitrosonium ion 635 has been shown to be highly reactive with glutathione and cause lipid peroxidation of cell 636 membranes.

637 Cocaine has been used to induce ALF in mice, though not commonly. Hayase et al. (2000) 638 administered cocaine at $65 \mathrm{mg} / \mathrm{kg}$ IP to male ICR mice. This resulted in serum ALT $>7,000 \mathrm{U} / \mathrm{L}$ at 63923 hours and significant neurological depression, though this normalized by 72 hours. Because of 
640 its other systemic effects, as well as its illicit status in most countries, it is likely to remain of

641 interest for its specific toxicology, rather than as a generalized ALF model.

642 Several other compounds for inducing acute hepatotoxicity, including allyl alcohol, 643 bromobenzene, diclofenac, furosemide, and N-nitrosodimethylamine, have been reported less 644 commonly in the literature (Brodie et al., 1971; Belinsky et al., 1985; Ilic et al., 2011; Loukopoulos 645 et al., 2014; McGill et al., 2015). However, because synthetic function and features of HE are not 646 routinely reported especially in rodent models, it is not clear whether these constitute reasonable 647 models for ALF on the basis of serum transaminases and histology. Sasaki et al. (2016) were able 648 to induce ALF in a rodent model using carbamazepine. Specific considerations in this model 649 include to use of F344 rats, daily dosing of carbamazepine for 5 days, and the co-administration 650 of BSO (a GSH-depleting agent) on the final day. These rats demonstrated significant elevations 651 in serum transaminases, with ALT peaking at 16,603U/L 24 hours after the last dose, as well as 652 centrilobular hepatocyte necrosis on histology. This study provides an example of a model of 653 idiosyncratic, drug-induced causes of liver failure.

654 There are a few specific approaches to idiosyncratic drug-induced liver injury (DILI). One 655 consists of co-administration of the drug with LPS, which is thought to add an inflammatory 656 stimulus to precipitate DILI. This approach has been shown to enhance hepatotoxicity in animal 657 models using amiodarone, chlorpromazine, diclofenac, halothane, ranitidine, and trovafloxacin 658 (Buchweitz et al., 2002; Luyendyk et al., 2003; Deng et al., 2006; Shaw et al., 2007; Dugan et al., 659 2010; Lu et al., 2012). However, the role of infection or inflammation as a causative factor in 660 human DILI has not been clearly demonstrated (McGill \& Jaeschke, 2019). An alternative 661 approach attempts to suppress immune tolerance of the liver, such as by knockout of programmed 
662 cell death protein 1 (PD-1), which, though it has been shown to increase susceptibility to ALI, has

663 not yet been shown to induce clear ALF (Metushi, Hayes \& Uetrecht, 2015).

664 In addition to the above-mentioned models of hepatotoxicity, administration of ammonia

665 directly (either PO or IV) has been used for the acute induction of HE in isolation (Fick, Schalm

666 \& de Vlieger, 1989; Butterworth et al., 2009). These artificial models of hyperammonemia may

667 be more appropriate as a control alongside acute or chronic models of liver injury, given the 668 absence other features of ALF and lack of a clinical correlate.

669

670

\section{Immunogenic Models of ALF}

The immune response, both the activation of resident immune cells and infiltration of 672 peripheral lymphocytes, features prominently in many of the models previously described. 673 However, we reserve this section for methods of inducing ALF primarily by direct immune674 mediated damage. The one exception is LPS, which would otherwise fit in this category, but was 675 described in conjunction with d-Gal because of their close association in ALF models. We will 676 describe the most well-established models, though the addition of knockout mice and genetically 677 modified viruses introduces complexity and variation that cannot fully be covered here.

\section{Concanavalin A}

679 Concanavalin A (ConA) initiates immune-mediated liver injury and has been used 680 specifically to model autoimmune hepatitis (Heymann et al., 2015). ConA is a lectin derived from

681 the jack bean (Canavalia ensiformis) that binds to various sugars, including glycoproteins and 682 glycolipids, mainly through interaction with mannose and glucose moieties. Hepatic injury after 683 ConA administration occurs primarily by the recruitment and activation of T cells and natural killer $684 \mathrm{~T}$ cells in the liver. ConA targets the liver specifically, where it is taken up by liver sinusoidal 
685 endothelial cells (LSECs). By itself, ConA has been shown to be minimally toxic to isolated 686 hepatocytes. In vitro studies have shown that the presence of lymphocytes and macrophages is 687 necessary to stimulate the release of TNF- $\alpha$ and other inflammatory cytokines by LSECs (Gantner 688 et al., 1995).

689 ConA for the induction of ALF is well described in mice, though not well characterized in 690 other animal models. ConA is dosed between $8-35 \mathrm{mg} / \mathrm{kg} \mathrm{IV}$, dissolved in sterile PBS or NS (it is 691 unknown whether it can be administered with the same effect IP) (Byk et al., 2016; Tadokoro et 692 al., 2017). Dose finding experiments are recommended prior to beginning experiments, as its 693 efficacy is known to vary by batch. As well, variations in susceptibility by age, sex, and strain have 694 been observed. In particular, female mice have been noted to have higher susceptibility and also 695 greater variability in outcome (Takamoto et al., 2003).

696 Wang et al. (2017) administered doses of $10 \mathrm{mg} / \mathrm{kg}$ to male C57BL/6 mice and reported 697 dramatic elevations in $\operatorname{ALT}(>8,000 \mathrm{U} / \mathrm{L})$ as soon as $12 \mathrm{~h}$ after injection. This corresponded with 698 greater than 50\% necrosis on histology. However, at this dose serum transaminases eventually 699 normalized and mice survived to at least $72 \mathrm{~h}$. In contrast, a higher dose of $25 \mathrm{mg} / \mathrm{kg}$ resulted in $70080 \%$ mortality by $48 \mathrm{~h}$.

701 There may be other lectins that produce a similar effect. For instance, Yu et al. (2020) used 702 a lectin purified from the edible mushroom Agrocybe aegerita (AAGL) to induce ALF in male $703 \mathrm{C} 57 \mathrm{BL} / 6$ mice. Administered at a dose of 3mg/kg PO, AAGL resulted in elevation in serum ALT $704>3,000 \mathrm{U} / \mathrm{L}$ and massive hepatocyte necrosis on histology within 9h. In contrast with ConA, liver 705 injury caused by AAGL was found to be associated with natural killer T cell infiltration, mediated 706 by IL-1 $\beta$. Other immunostimulatory macromolecules, such as $\alpha$-galactosylceramide, have been 
707 used to induce an immune-mediated hepatitis, but have not been convincingly shown to model

708 ALF (Biburger \& Tiegs, 2005).

709 Fas Antibody

710 A specific Fas antibody has been used in animal models to induce ALF. It is a monoclonal

711 antibody (Jo-2 clone) produced by Pharmingen (a subsidiary of BD Sciences) by exposure of

712 Armenian hamster to a mouse lymphoma cell line transformed with recombinant Fas. It binds to

713 and activates Fas receptor (CD95) inducing apoptosis. Though Fas is expressed by other tissues,

714 including thymus, heart, lung, and ovary, this anti-Fas antibody has been used to specifically

715 induce ALF in animal models.

716 Fas antibody is typically given IV by tail vein injection in doses ranging from 100 to

$717600 \mu \mathrm{g} / \mathrm{kg}$, but may alternatively be administered IP (Bajt et al., 2000; Mizuguchi et al., 2007).

718 There is a potential theoretical benefit to IP administration, as it would be more likely to enter the

719 portal circulation (Turner et al., 2011). The Fas antibody acts on hepatocytes, as well as

720 nonparenchymal liver cells. Malassagne et al. (2001) reported rapid lethality - 100\% mortality

721 within $8 \mathrm{~h}$ - with a dose of $250 \mu \mathrm{g} / \mathrm{kg}$ in female BALB/c mice. When lowering the dose to $150 \mu \mathrm{g} / \mathrm{kg}$,

722 animals survived to at least $12 \mathrm{~h}$, but still developed substantial liver injury, with AST rising to

$723>5,000 \mathrm{U} / \mathrm{L}$ and severe lesions on histology. Sharma et al. (2011), testing a higher dose of

$724400 \mu \mathrm{g} / \mathrm{kg}$, reported $100 \%$ mortality within $20 \mathrm{~h}$ and elevated ALT $>800 \mathrm{U} / \mathrm{L}$ at $9 \mathrm{~h}$. It is possible

725 that the discrepancy is the result of sex differences which were not reported in this study.

726 Viral Models of ALF

727 In addition to the variety of models that may be created using recombinant genetic techniques

728 on the virus and/or host, there are several species-specific viruses associated with fatal hepatitis in

729 wild type animals. Mice are susceptible to murine hepatitis virus (MHV) strain 3, a species of 
730 coronavirus. Like all coronaviruses, MHV is an enveloped, positive sense, single stranded RNA

731 virus (Roth-Cross, Bender \& Weiss, 2008). It affects the brain and/or liver, producing acute or

732 chronic injury depending on the specific strain. MHV strain 3 results in ALF in susceptible mice

733 strains. Studies typically use BALB/c mice. Some strains, such as A/J mice are completely

734 resistant, whereas others, such as $\mathrm{C} 3 \mathrm{H}$ mice, tend to develop non-lethal acute hepatitis, progressing

735 to chronic hepatitis. Following viral replication and lysis in Kupffer cells and LSECs at the liver

736 sinusoids, MHV infects hepatocytes, resulting in focal necrosis (Martin et al., 1994).

737 Studies have been reported dosing 6-8wk old female BALB/c mice with 20 plaque forming

738 units (PFUs) of MHV that resulted in 100\% mortality within 3-5 days and serum ALT of 2,000-

$7392,500 \mathrm{U} / \mathrm{L}$ at $60 \mathrm{~h}$. Histology showed focal necrosis and massive inflammatory cell infiltrate (Zhu

740 et al., 2006; Gao et al., 2010). Other studies, using the high doses of 100 PFU in BALB/c mice of

741 the same sex and age, have reported ALT in excess of $10,000 \mathrm{U} / \mathrm{L}$ at $72 \mathrm{~h}$ and enlarging focal

742 necrosis, becoming confluent, between 48 to $72 \mathrm{~h}$ (Wu et al., 2016; Yu et al., 2017).

743 Other strains of MHV, including MHV-2, MHV-A59, and MHV-JHM, have also been

744 reported to induce significant hepatitis (Garcia et al., 2021). For instance, MHV-A59 has been

745 shown to cause elevated serum AST of 3,700U/L 24h after administration of 16 complement

746 fixation units to female CD mice (Farivar et al., 1976). Histological sections from livers of these

747 mice correspondingly showed greater than $90 \%$ necrosis of hepatocytes.

748 Rabbit hemorrhagic disease virus (RHDV) is a species of calicivirus affecting wild and

749 domestic European rabbits (Oryctolagus cuniculus) that causes acute hepatic necrosis,

750 disseminated intravascular coagulopathy and rapid demise (Belz, 2004). RHDV is a positive sense,

751 single stranded RNA spread by airborne and fecal-oral transmission. Studies administering $2 \times 10^{4}$

752 hemagglutination units of RHDV via intramuscular (IM) injection to 9wk old New Zealand white 
753 rabbits have reported mortality of $90-100 \%$ by $60 \mathrm{~h}$, with serum ALT reaching between 1,500 -

754 3,500IU/L at 48h (San-Miguel et al., 2006; García-Lastra et al., 2010; Tuñon et al., 2011).

755 Histology showed expected changes of extensive hepatocellular necrosis, edema, hemorrhage, and

756 neutrophil infiltration. Sánchez-Campos et al. (2004) reported elevated PT and decreased factor

757 VII at $48 \mathrm{~h}$ compared to baseline in addition to elevated transaminases, but it is unclear to what

758 degree this is a consequence of liver failure versus coagulopathic effects induced by the virus.

759 While no species-specific viral hepatitides are known in non-human primates, attempts have

760 been made to induce ALF using human viruses, though with limited success. Leon et al. (2016)

761 co-infected three M. fasicularis macaques with parvovirus B19 and hepatitis A virus (HAV), as

762 this is known to worsen the resultant hepatitis. Despite demonstrating appropriate seroconversion,

763 the animals did not develop ALF and findings on liver histology were only slightly worse

764 compared to animals infected with HAV alone. Lashkevich et al. (1996) described the rapid

765 development of encephalopathy and hepatic necrosis in 'monkeys' after administration of

766 echoviruses isolated from severe pediatric cases. However, details on these cases are lacking and

767 viral genotypes were not reported.

768 Hepatitis B virus (HBV) is known to cause an acute hepatitis in chimpanzees (Pan

769 troglodytes). However, the development of ALF has not been reported. Chen et al. (2020) infected

770 chimpanzees with a procure HBV mutant that is known to be associated with ALF in humans.

771 While the hepatitis induced by the variant was more severe than that caused by the wild type, none

772 of the animals developed ALF and all had completely recovered within 24 weeks. Given that ALF

773 occurs only $1 \%$ of cases of acute hepatitis B in human patients, it may not be possible to achieve

774 sufficient consistency for use in primate models (Manka et al., 2016). 

interferon- $\alpha / \beta$ receptor or antibody blockade, has been used in several studies to reliably induce ALF by a range of viruses that would otherwise not result in hepatitis or only sporadically so. Type I IFNs, including IFN $\alpha$ and $\beta$ as the most well-known, play an important role in the acute antiviral response by inhibiting viral replication and spread by infected cells, promoting viral antigen presentation, and activating the adaptive immune system (Murira \& Lamarre, 2016). Lindquist et al. (2018) reported a model of Crimean-Congo hemorrhagic fever virus (CCHFV) induced-liver injury in $\mathrm{C} 57 \mathrm{Bl} / 6$ mice relying on type I IFN blockade by anti-interferon $\alpha / \beta$ receptor subunit 1 (IFNAR1) antibody. Mice infected with 100 PFUs of CCHFV, followed by IFN-I blockade 24h later, demonstrated elevated serum transaminases into the several hundreds, widespread inflammation and hepatocellular necrosis on histology, and uniform lethality within 5 days. type II IFN blockade (via STAT1 knockout) to achieve ALF by herpes simplex virus type 1 (HSVtransaminases $(>12,000 \mathrm{U} / \mathrm{L})$ and death by 5 days. Histology showed multifocal necrosis, with infiltrating neutrophils and lymphocytes.

\section{Other Models of Immune-Mediated ALF}

795 Other immunogenic models of ALF have employed a combination of strategies to yield ALF 
798 virus infection (Kim, Chang \& Shin, 2014). In their model, mice that had been either immunized

799 against chicken ovalbumin (OVA) and/or treated with OVA-specific CD8 T cells (OT-I cells) were

800 exposed to a recombinant adenovirus coding for OVA 30 days after immunization. A third group

801 was treated with OT-I cells at the same time as being exposed to the recombinant virus. All three

802 groups showed a dramatic rise in serum ALT 3 days post-infection, with the highest elevation

$803(>7,000 \mathrm{U} / \mathrm{L})$ being found in the third group (combined administration of OT-I cells and virus).

804 Histology showed extensive periportal infiltration of T cells, with confluent areas of hepatocyte 805 necrosis.

806 A model of autoimmune hepatitis (AIH) was described by Kido et al. (2008), in which PD-

8071 knockout BALB/c mice undergo thymectomy at 3 days old, leading to the spontaneous 808 development of AIH within several weeks. These mice showed onset of AIH between 2-3wks, 809 marked by peak AST >3,000 U/L and fatality of all mice by 4 wks. These mice developed anti810 nuclear antibodies, a key feature of AIH type 1 in humans, and histology showed severe hepatocyte 811 degeneration, with massive infiltration of CD4+ and CD8+ T cells.

812 Knockout models such as these, as well as those of IFN pathways, may be less useful in

813 directly investigating novel therapies, compared to models of wild-type mice. However, they play

814 a greater role in understanding the underlying pathophysiology of viral and immune-mediated

815 forms of ALF.

816

817 Other Models

818 The final model of ALF that will be discussed is the Long Evans Cinnamon (LEC) rat, which

819 is distinct from the other categories of preclinical models and serves as a specific model of

820 Wilson's disease, an autosomal recessive disease of abnormal copper metabolism that can lead to 
821 both acute and chronic liver failure in humans (Członkowska et al., 2018). LEC rats have a genetic

822 defect in the gene encoding a copper transporting P-type ATPase, homologous to the $A T P 7 B$ gene

823 that is known to be responsible for Wilson's disease in humans (Terada \& Sugiyama, 1999). As in

824 their human counterparts, they demonstrate excessive deposition of copper in the liver, decreased

825 serum copper and its transporter, ceruloplasmin, as well as decreased biliary excretion. Hepatitis

826 and ALF occurs spontaneously in these animals between 80 and 120 days old (Li et al., 1991).

827 ALF can be more reliably induced in these animals by dietary copper supplementation or 828 acute administration of copper. Siaj et al. (2012) demonstrated that LEC rats receiving water 829 supplemented with $20 \mathrm{mg}$ of copper per litre over 3 months resulted in ALF by 80 days, compared 830 to animals receiving reduced copper diets, which could prevent hepatitis and ensure almost 831 disease-free survival. Interestingly, rats transitioned to high copper diet after 5 months on a regular 832 diet had more rapid elevation of serum transaminases and showed decreased mean lifespan 833 compared to rats receiving the high copper diet for 3 months beginning as pups. Still, both groups 834 developed elevated serum transaminases, peaking at $\sim 1,000 \mathrm{U} / \mathrm{L}$, and had histology showed 835 extensive inflammation, enlarged nuclei, and, to a lesser extent, necrosis. IP injection of $3 \mathrm{mg} / \mathrm{kg}$ 836 of copper daily for 3 days has been shown to rapidly induced ALF in LEC rats, with death 837 occurring in $50 \%$ of animals by $48 \mathrm{~h}$ (Sugawara et al., 1991).

838

839 8. Concluding Remarks

840 Acute liver failure in patients presents two distinct opportunities for effective intervention

841 aimed at improving outcomes. The first is at initial presentation to mitigate acute hepatic necrosis.

842 The second is in the days that follow to enhance liver regeneration. Preclinical models of ALF 843 largely represent models of acute hepatocyte death and their role in the study of pathophysiology 
844 and potential therapeutic interventions applies mostly to the former aspect. As opposed to clinical

845 cases, the focus is on markers of hepatocyte death, chiefly serum transaminases and histology,

846 rather than liver function. Particularly, with their brief time course and the lack of reversibility of

847 some models, they are best used to investigate factors that play a role in this phase, as well as 848 opportunities for intervention.

849 As with any animal model of clinical disease, the goal should be to identify essential 850 elements and eliminate extraneous details to enhance reproducibility, both within the same study 851 and for others trying to replicate it. To paraphrase Albert Einstein, animal models should be "as 852 simple as possible, but no simpler" (Robinson, 2018). Some have sought a generalized model of 853 ALF, while others aim to reproduce a specific cause of ALF seen clinically. Still, other models 854 represent a particular type of ALF, whose specific causes are not easily reproduced in the 855 preclinical setting, such as ConA for immune causes of ALF. Generalized models may be 856 appropriate for evaluating treatments meant to be broadly applicable and may prove to be more 857 reproducible in some instances. However, given complexities of ALF and its multiple etiologies, 858 it is difficult to know how well insights gained from any single model will apply to the clinical 859 setting. It is likely that judicious use of a variety of animal models will continue to be required to 860 enhance our understanding of and explore effective treatment options for ALF.

861

\section{Acknowledgements}

863 BAMG is supported by the Patronato del Instituto Nacional de Ciencias Medicas y Nutricion

864 Salvador Zubiran (INCMNSZ), the Fundación para la Salud y la Educación Dr. Salvador Zubirán 865 (FunSaEd), and the CHRISTUS Excellence and Innovation Center. AMJS holds a Canada 866 Research Chair in Transplantation Surgery and Regenerative Medicine. 
867

868

References

869

Abe Y, Hines IN, Zibari G, Pavlick K, Gray L, Kitagawa Y, Grisham MB. 2009. Mouse model

870

of liver ischemia and reperfusion injury: method for studying reactive oxygen and nitrogen

871 metabolites in vivo. Free Radical Biology and Medicine 46:1-7. DOI:

872 10.1016/j.freeradbiomed.2008.09.029.

873 Abrantes J, van der Loo W, Le Pendu J, Esteves PJ. 2012. Rabbit haemorrhagic disease (RHD)

874 and rabbit haemorrhagic disease virus (RHDV): a review. Veterinary Research 43:12. DOI:

$875 \quad 10.1186 / 1297-9716-43-12$.

876 Agoston DV. 2017. How to Translate Time? The Temporal Aspect of Human and Rodent Biology.

877 Frontiers in Neurology 8:92. DOI: 10.3389/fneur.2017.00092.

878 Akhtar T, Sheikh N. 2013. An overview of thioacetamide-induced hepatotoxicity. Toxin Reviews

879 32:43-46. DOI: $10.3109 / 15569543.2013 .805144$.

880 Allen TM, Brehm MA, Bridges S, Ferguson S, Kumar P, Mirochnitchenko O, Palucka K,

881 Pelanda R, Sanders-Beer B, Shultz LD, Su L, PrabhuDas M. 2019. Humanized immune system

882 mouse models: progress, challenges and opportunities. Nature Immunology 20:770-774. DOI:

883 10.1038/s41590-019-0416-Z.

884 Alp MH, Hickman R. 1987. The effect of prostaglandins, branched-chain amino acids and other

885 drugs on the outcome of experimental acute porcine hepatic failure. Journal of Hepatology 4:99-

886 107. DOI: $10.1016 / \mathrm{S} 0168-8278(87) 80016-8$.

887 Apte U. 2014. Galactosamine. In: Wexler P ed. Encyclopedia of Toxicology (Third Edition).

888 Oxford: Academic Press, 689-690. DOI: 10.1016/B978-0-12-386454-3.00315-8. 
889 Argibay PF, Vazquez JC, Hyon SH, Garcia H, Nuñez F. 1996. Polyacrylonitrile Membrane

890 Interposition Between a Xenograft and an Animal in Fulminant Liver Failure: The Concept of

891 Xenohemodiafiltration. ASAIO Journal 42:M411.

892 Arkadopoulos N, Chen SC, Khalili TM, Detry O, Hewitt WR, Lilja H, Kamachi H, Petrovic

893 L, Mullon CJ, Demetriou AA, Rozga J. 1998. Transplantation of hepatocytes for prevention of

894 intracranial hypertension in pigs with ischemic liver failure. Cell Transplantation 7:357-363. DOI:

895 10.1016/s0963-6897(98)00027-x.

896 Arkadopoulos N, Defterevos G, Nastos C, Papalois A, Kalimeris K, Papoutsidakis N,

897 Kampouroglou G, Kypriotis D, Pafiti A, Kostopanagiotou G, Smyrniotis V. 2011.

898 Development of a Porcine Model of Post-Hepatectomy Liver Failure. Journal of Surgical

899 Research 170:e233-e242. DOI: 10.1016/j.jss.2011.06.006.

900 Asencio JM, García-Sabrido JL, López-Baena JA, Olmedilla L, Peligros I, Lozano P,

901 Morales-Taboada Á, Fernández-Mena C, Steiner MA, Sola E, Perez-Peña JM, Herrero M,

902 Laso J, Lisbona C, Bañares R, Casanova J, Vaquero J. 2017. Preconditioning by portal vein

903 embolization modulates hepatic hemodynamics and improves liver function in pigs with extended

904 hepatectomy. Surgery 161:1489-1501. DOI: 10.1016/j.surg.2016.12.003.

905 Ash SR, Carr DJ, Blake DE, Rainier JB, Demetriou AA, Rozga J. 1993. Effect of sorbent-

906 based dialytic therapy with the BioLogic-DT on an experimental model of hepatic failure. ASAIO

907 journal (American Society for Artificial Internal Organs: 1992) 39:M675-680.

908 Baimakhanov Z, Yamanouchi K, Sakai Y, Koike M, Soyama A, Hidaka M, Takatsuki M,

909 Fujita F, Kanetaka K, Kuroki T, Eguchi S. 2016. Efficacy of Multilayered Hepatocyte Sheet

910 Transplantation for Radiation-Induced Liver Damage and Partial Hepatectomy in a Rat Model.

911 Cell Transplantation 25:549-558. DOI: 10.3727/096368915X688669. 
912 Bajt ML, Lawson JA, Vonderfecht SL, Gujral JS, Jaeschke H. 2000. Protection against Fas

913 Receptor-Mediated Apoptosis in Hepatocytes and Nonparenchymal Cells by a Caspase-8 Inhibitor

914 in Vivo: Evidence for a Postmitochondrial Processing of Caspase-8. Toxicological Sciences

915 58:109-117. DOI: $\underline{10.1093 / \text { toxsci/58.1.109. }}$.

916 Barman PK, Mukherjee R, Prusty BK, Suklabaidya S, Senapati S, Ravindran B. 2016.

917 Chitohexaose protects against acetaminophen-induced hepatotoxicity in mice. Cell Death \& 918 Disease 7:e2224-e2224. DOI: $10.1038 /$ cddis.2016.131.

919 Bélanger M, Butterworth RF. 2005. Acute liver failure: a critical appraisal of available animal

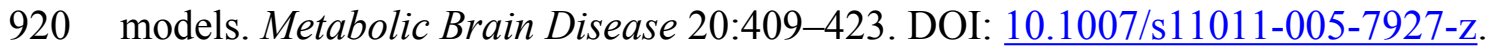

921 Belinsky SA, Bradford BU, Forman DT, Glassman EB, Felder MR, Thurman RG. 1985.

922 Hepatotoxicity due to allyl alcohol in deermice depends on alcohol dehydrogenase. Hepatology

923 5:1179-1182. DOI: $\underline{\text { 10.1002/hep.1840050619. }}$

924 Belz K. 2004. Rabbit hemorrhagic disease. Seminars in Avian and Exotic Pet Medicine 13:100925 104. DOI: $10.1053 /$ j.saep.2004.01.006.

926 Berlinger WG, Stene RA, Spector R, Al-Jurf AS. 1987. Plasma and cerebrospinal fluid 927 nucleosides and oxypurines in acute liver failure. The Journal of Laboratory and Clinical Medicine 928 110:137-144.

929 Biburger M, Tiegs G. 2005. $\alpha$-Galactosylceramide-Induced Liver Injury in Mice Is Mediated by 930 TNF- $\alpha$ but Independent of Kupffer Cells. The Journal of Immunology 175:1540-1550. DOI: $931 \quad$ 10.4049/jimmunol.175.3.1540.

932 Birraux J, Genin B, Sinigaglia C, Mage R, Morel P, Coultre CL. 1998. Does Hepatocyte

933 Transplantation in a Chemically Induced Acute Hepatic Failure Make Sense? European Journal 934 of Pediatric Surgery 8:224-229. DOI: $10.1055 / \mathrm{s}-2008-1071159$. 
935 Boll M, Lutz WD, Becker E, Stampfl A. 2001. Mechanism of Carbon Tetrachloride-Induced 936 Hepatotoxicity. Hepatocellular Damage by Reactive Carbon Tetrachloride Metabolites. Zeitschrift

937 für Naturforschung C 56:649-659. DOI: 10.1515/znc-2001-7-826.

938 Bonato C, Malesci A, Rosati R, Vignati F, Montorsi M, Bersani M, Abbiati R, Salerno F. 939 1989. Brain cholecystokinin depletion in rats with acute liver failure. Life Sciences 44:131-135.

940 DOI: $\underline{10.1016 / 0024-3205(89) 90530-4 .}$.

941 Borst K, Frenz T, Spanier J, Tegtmeyer P-K, Chhatbar C, Skerra J, Ghita L, Namineni S,

942 Lienenklaus S, Köster M, Heikenwaelder M, Sutter G, Kalinke U. 2018. Type I interferon

943 receptor signaling delays Kupffer cell replenishment during acute fulminant viral hepatitis.

944 Journal of Hepatology 68:682-690. DOI: 10.1016/j.jhep.2017.11.029.

945 Brodie BB, Reid WD, Cho AK, Sipes G, Krishna G, Gillette JR. 1971. Possible Mechanism of 946 Liver Necrosis Caused by Aromatic Organic Compounds. Proceedings of the National Academy 947 of Sciences 68:160-164. DOI: 10.1073/pnas.68.1.160.

948 Brodsky M, Hirsh S, Albeck M, Sredni B. 2009. Resolution of inflammation-related apoptotic

949 processes by the synthetic tellurium compound, AS101 following liver injury. Journal of 950 Hepatology 51:491-503. DOI: 10.1016/j.jhep.2009.04.024.

951 Buchweitz JP, Ganey PE, Bursian SJ, Roth RA. 2002. Underlying Endotoxemia Augments

952 Toxic Responses to Chlorpromazine: Is There a Relationship to Drug Idiosyncrasy? Journal of 953 Pharmacology and Experimental Therapeutics 300:460-467. DOI: 10.1124/jpet.300.2.460.

954 Budras K-D, McCarthy PH, Fricke W, Richter R. Anatomy of the Dog. $5^{\text {th }}$ ed. Hannover:

955 Schlütersche; 2007. Chapter 6: Abdominal Cavity. p. 50-61.

956 Bustos M, Beraza N, Lasarte J-J, Baixeras E, Alzuguren P, Bordet T, Prieto J. 2003.

957 Protection against liver damage by cardiotrophin-1: a hepatocyte survival factor up-regulated in 
958 the regenerating liver in rats. Gastroenterology 125:192-201. DOI: $\underline{10.1016 / \text { S0016- }}$ 959 5085(03)00698-X.

960 Butterworth RF, Norenberg MD, Felipo V, Ferenci P, Albrecht J, Blei AT. 2009.

961 Experimental models of hepatic encephalopathy: ISHEN guidelines. Liver International 29:783-

962 788. DOI: $\underline{10.1111 / \mathrm{j} .1478-3231.2009 .02034 . \mathrm{x}}$.

963 Byk K, Jasinski K, Bartel Z, Jasztal A, Sitek B, Tomanek B, Chlopicki S, Skorka T. 2016.

964 MRI-based assessment of liver perfusion and hepatocyte injury in the murine model of acute 965 hepatitis. Magnetic Resonance Materials in Physics, Biology and Medicine 29:789-798. DOI: $966 \quad \underline{10.1007 / \mathrm{s} 10334-016-0563-2}$.

967 Cao H, Yang J, Yu J, Pan Q, Li J, Zhou P, Li Y, Pan X, Li J, Wang Y, Li L. 2012. Therapeutic 968 potential of transplanted placental mesenchymal stem cells in treating Chinese miniature pigs with 969 acute liver failure. BMC Medicine 10:56. DOI: 10.1186/1741-7015-10-56.

970 Cauli O, Rodrigo R, Boix J, Piedrafita B, Agusti A, Felipo V. 2008. Acute liver failure-induced

971 death of rats is delayed or prevented by blocking NMDA receptors in brain. American Journal of

972 Physiology-Gastrointestinal and Liver Physiology 295:G503-G511. DOI:

973 10.1152/ajpgi.00076.2008.

974 Chen E-Q, Gong D-Y, Leng X-H, Bai L, Liu C, Wang L-C, Tang H. 2012. Inhibiting the

975 expression of hepatocyte nuclear factor 4 alpha attenuates lipopolysaccharide/D-galactosamine-

976 induced fulminant hepatic failure in mice. Hepatobiliary \& Pancreatic Diseases International

977 11:624-629. DOI: $\underline{10.1016 / \mathrm{S} 1499-3872(12) 60235-5 .}$.

978 Chen Z, Engle RE, Shen C-H, Zhao H, Schuck PW, Danoff EJ, Nguyen H, Nishimura N,

979 Bock KW, Moore IN, Kwong PD, Purcell RH, Govindarajan S, Farci P. 2020. Distinct disease 
980 features in chimpanzees infected with a precore HBV mutant associated with acute liver failure in 981 humans. PLOS Pathogens 16:e1008793. DOI: 10.1371/journal.ppat.1008793.

982 Chiam E, Bellomo R, Churilov L, Weinberg L. 2018. The hemodynamic effects of intravenous 983 paracetamol (acetaminophen) vs normal saline in cardiac surgery patients: A single center placebo 984 controlled randomized study. PLOS ONE 13:e0195931. DOI: 10.1371/journal.pone.0195931.

985 Choi JS, Burm JP. 2005. Pharmacokinetics of verapamil and its major metabolite, nor-verapamil 986 from oral administration of verapamil in rabbits with hepatic failure induced by carbon 987 tetrachloride. Archives of Pharmacal Research 28:483-487. DOI: 10.1007/BF02977680.

988 Członkowska A, Litwin T, Dusek P, Ferenci P, Lutsenko S, Medici V, Rybakowski JK, Weiss

989 KH, Schilsky ML. 2018. Wilson disease. Nature Reviews Disease Primers 4:1-20. DOI: $990 \quad 10.1038 / \mathrm{s} 41572-018-0018-3$.

991 Dahm LJ, Ganey PE, Roth RA. 2010. 9.25 - $\alpha$-Naphthylisothiocyanate. In: McQueen CA ed. 992 Comprehensive Toxicology (Second Edition). Oxford: Elsevier, 571-579. DOI: 10.1016/B978-0993 08-046884-6.01024-1.

994 Deng X, Stachlewitz RF, Liguori MJ, Blomme EAG, Waring JF, Luyendyk JP, Maddox JF, 995 Ganey PE, Roth RA. 2006. Modest Inflammation Enhances Diclofenac Hepatotoxicity in Rats: 996 Role of Neutrophils and Bacterial Translocation. Journal of Pharmacology and Experimental 997 Therapeutics 319:1191-1199. DOI: 10.1124/jpet.106.110247.

998 Doering CB, Josephson CD, Craddock HN, Lollar P. 2002. Factor VIII expression in 999 azoxymethane-induced murine fulminant hepatic failure. Blood 100:143-147. DOI: $1000 \quad$ 10.1182/blood.V100.1.143.

1001 Du K, Williams CD, McGill MR, Jaeschke H. 2014. Lower susceptibility of female mice to 1002 acetaminophen hepatotoxicity: Role of mitochondrial glutathione, oxidant stress and c-jun N- 
1003 terminal kinase. Toxicology and Applied Pharmacology 281:58-66. DOI: 1004 10.1016/j.taap.2014.09.002.

1005 Dugan CM, MacDonald AE, Roth RA, Ganey PE. 2010. A Mouse Model of Severe Halothane 1006 Hepatitis Based on Human Risk Factors. Journal of Pharmacology and Experimental Therapeutics 1007 333:364-372. DOI: 10.1124/jpet.109.164541.

1008 Egleston CV, Browning C, Hamdi I, Campbell-Hewson G, Robinson SM. 1997. Comparison 1009 of two assays for measuring plasma concentrations of paracetamol. BMJ : British Medical Journal $1010 \quad 315: 991-992$.

1011 Eguchi S, Kamlot A, Ljubimova J, Hewitt WR, Lebow LT, Demetriou AA, Rozga J. 1996. 1012 Fulminant hepatic failure in rats: Survival and effect on blood chemistry and liver regeneration. 1013 Hepatology 24:1452-1459. DOI: 10.1002/hep.510240626.

1014 El Khiat A, Tamegart L, Draoui A, El Fari R, Sellami S, Rais H, El Hiba O, Gamrani H. 1015 2019. Kinetic deterioration of short memory in rat with acute hepatic encephalopathy: Involvement 1016 of astroglial and neuronal dysfunctions. Behavioural Brain Research 367:201-209. DOI: $1017 \quad$ 10.1016/j.bbr.2019.03.046.

1018 Ezran C, Karanewsky CJ, Pendleton JL, Sholtz A, Krasnow MR, Willick J, Razafindrakoto 1019 A, Zohdy S, Albertelli MA, Krasnow MA. 2017. The Mouse Lemur, a Genetic Model Organism 1020 for Primate Biology, Behavior, and Health. Genetics 206:651-664. DOI: $1021 \quad 10.1534 /$ genetics.116.199448.

1022 Farivar M, Wands JR, Isselbacher KJ, Bucher NLR. 1976. Effect of Insulin and Glucagon on 1023 Fulminant Murine Hepatitis. New England Journal of Medicine 295:1517-1519. DOI: 1024 10.1056/NEJM197612302952706. 
1025 Feng L, Cai L, He G-L, Weng J, Li Y, Pan M-X, Jiang Z-S, Peng Q, Gao Y. 2017. Novel D-

1026 galactosamine-induced cynomolgus monkey model of acute liver failure. World Journal of

1027 Gastroenterology 23:7572-7583. DOI: 10.3748/wjg.v23.i42.7572.

1028 Ferenci P, Pappas SC, Munson PJ, Henson K, Jones EA. 1984. Changes in the Status of

1029 Neurotransmitter Receptors in a Rabbit Model of Hepatic Encephalopathy. Hepatology 4:186-

1030 191. DOI: $10.1002 /$ hep.1840040204.

1031 Ferriero R, Nusco E, De Cegli R, Carissimo A, Manco G, Brunetti-Pierri N. 2018. Pyruvate

1032 dehydrogenase complex and lactate dehydrogenase are targets for therapy of acute liver failure.

1033 Journal of Hepatology 69:325-335. DOI: 10.1016/j.jhep.2018.03.016.

1034 Fiala ES, Joseph C, Sohn OS, el-Bayoumy K, Reddy BS. 1991. Mechanism of

1035 benzylselenocyanate inhibition of azoxymethane-induced colon carcinogenesis in F344 rats.

1036 Cancer Research 51:2826-2830.

1037 Fick TE, Schalm SW, Vlieger M de. 1987. A Surgical Model of Fulminant Hepatic Failure in 1038 the Rabbit: Different Effects of End-to-Side versus Small-Diameter Side-to-Side Portacaval Shunt.

1039 European Surgical Research 19:276-282. DOI: 10.1159/000128710.

1040 Fick TE, Schalm SW, de Vlieger M. 1989. Continuous intravenous ammonia infusion as a model

1041 for the study of hepatic encephalopathy in rabbits. Journal of Surgical Research 46:221-225. DOI:

$1042 \quad \underline{10.1016 / 0022-4804(89) 90060-7 .}$.

1043 Filipponi F, Fabbri LP, Marsili M, Falcini F, Benassai C, Nucera M, Romagnoli P. 1991. A

1044 New Surgical Model of Acute Liver Failure in the Pig: Experimental Procedure and Analysis of 1045 Liver Injury. European Surgical Research 23:58-64. DOI: 10.1159/000129137. 
1046 Filipponi F, Boggi U, Meacci L, Burchielli S, Vistoli F, Bellini R, Prota C, Colizzi L, Kusmic

1047 C, Campani D, Gneri C, Trivella MG, Mosca F. 1999. A new technique for total hepatectomy

1048 in the pig for testing liver support devices. Surgery 125:448-455.

1049 Filipponi F, Mosca F. 2001. Animal models of fulminant hepatic failure: need to test liver support 1050 devices. Digestive and Liver Disease 33:607-613. DOI: 10.1016/S1590-8658(01)80116-X.

1051 Fourneau I. 2000. An Improved Model of Acute Liver Failure Based on Transient Ischemia of 1052 the Liver. Archives of Surgery 135:1183. DOI: 10.1001/archsurg.135.10.1183.

1053 Francavilla A, Makowka L, Polimeno L, Barone M, Demetris J, Prelich J, Van Thiel DH, 1054 Starzl TE. 1989. A Dog Model for Acetaminophen-Induced Fulminant Hepatic Failure. 1055 Gastroenterology 96:470-478.

1056 Frank D, Savir S, Gruenbaum BF, Melamed I, Grinshpun J, Kuts R, Knyazer B, Zlotnik A, 1057 Vinokur M, Boyko M. 2020. Inducing Acute Liver Injury in Rats via Carbon Tetrachloride 1058 (CC14) Exposure Through an Orogastric Tube. JoVE (Journal of Visualized Experiments):e60695. 1059 DOI: $10.3791 / 60695$.

1060 Frühauf NR, Oldhafer KJ, Westermann S, Sotiropoulos GC, Kaiser GM. 2004. Acute hepatic 1061 failure in swine: hepatectomy versus vascular occlusion. Journal of Investigative Surgery: The 1062 Official Journal of the Academy of Surgical Research 17:163-171. DOI: $1063 \underline{10.1080 / 08941930490446955 .}$

1064 Galun E, Zeira E, Pappo O, Peters M, Rose-John S. 2000. Liver regeneration induced by a 1065 designer human IL-6/ sIL-6R fusion protein reverses severe hepatocellular injury. The FASEB 1066 Journal 14:1979-1987. DOI: 10.1096/fj.99-0913com. 
1067 Ganai AA, Husain M. 2018. Genistein Alleviates Neuroinflammation and Restores Cognitive

1068 Function in Rat Model of Hepatic Encephalopathy: Underlying Mechanisms. Molecular

1069 Neurobiology 55:1762-1772. DOI: 10.1007/s12035-017-0454-1.

1070 Gantner F, Leist M, Lohse AW, Germann PG, Tiegs G. 1995. Concanavalin A—induced T-

1071 cell-Mediated hepatic injury in mice: The role of tumor necrosis factor. Hepatology 21:190-198.

1072 DOI: $\underline{10.1016 / 0270-9139(95) 90428-X}$.

1073 Gao S, Wang M, Ye H, Guo J, Xi D, Wang Z, Zhu C, Yan W, Luo X, Ning Q. 2010. Dual

1074 Interference with Novel Genes mfgl2 and mTNFR1 Ameliorates Murine Hepatitis Virus Type 3-

1075 Induced Fulminant Hepatitis in BALB/cJ Mice. Human Gene Therapy 21:969-977. DOI:

$1076 \quad \underline{10.1089 / \text { hum.2009.177. }}$

1077 Garcia AB, de Moraes AP, Rodrigues DM, Gilioli R, de Oliveira-Filho EF, Durães-Carvalho

1078 R, Arns CW. Coding-Complete Genome Sequence of Murine Hepatitis Virus Strain 3 from

1079 Brazil. Microbiology Resource Announcements 10:e00248-21. DOI: 10.1128/MRA.00248-21.

1080 García-Lastra R, San-Miguel B, Crespo I, Jorquera F, Alvarez M, González-Gallego J,

1081 Tuñón MJ. 2010. Signaling pathways involved in liver injury and regeneration in rabbit

1082 hemorrhagic disease, an animal model of virally-induced fulminant hepatic failure. Veterinary

1083 Research 41:1. DOI: 10.1051/vetres/2009050.

1084 Gazzard BG, Hughes RD, Mellon PJ, Portmann B, Williams R. 1975. A dog model of

1085 fulminant hepatic failure produced by paracetamol administration. British Journal of Experimental

1086 Pathology 56:408-411.

1087 de Groot GH, Reuvers CB, Schalm SW, Boks AL, Terpstra OT, Jeekel H, ten Kate FWJ,

1088 Bruinvels J. 1987. A reproducible model of acute hepatic failure by transient ischemia in the pig.

1089 Journal of Surgical Research 42:92-100. DOI: 10.1016/0022-4804(87)90070-9. 
1090 Guglielmi A, Ruzzenente A, Conci S, Valdegamberi A, Iacono C. 2012. How Much Remnant

1091 Is Enough in Liver Resection? Digestive Surgery 29:6-17. DOI: 10.1159/000335713.

1092 Hackam DG, Redelmeier DA. 2006. Translation of research evidence from animals to humans. 1093 JAMA 296:1731-1732. DOI: 10.1001/jama.296.14.1731.

1094 Hajovsky H, Hu G, Koen Y, Sarma D, Cui W, Moore DS, Staudinger JL, Hanzlik RP. 2012.

1095 Metabolism and Toxicity of Thioacetamide and Thioacetamide S-Oxide in Rat Hepatocytes.

1096 Chemical Research in Toxicology 25:1955-1963. DOI: 10.1021/tx3002719.

1097 Ham D-S, Song M-S, Park H-S, Rhee M, Yang HK, Lee S-H, Kim J-W, Jung E-S, Yoon K-

1098 H. 2015. Successful xenotransplantation with re-aggregated and encapsulated neonatal pig liver

1099 cells for treatment of mice with acute liver failure. Xenotransplantation 22:249-259. DOI:

$1100 \quad \underline{10.1111 / x e n .12177 .}$

1101 Hamesch K, Borkham-Kamphorst E, Strnad P, Weiskirchen R. 2015. Lipopolysaccharide-

1102 induced inflammatory liver injury in mice. Laboratory Animals 49:37-46. DOI: $1103 \quad 10.1177 / 0023677215570087$.

1104 Hayase T, Yamamoto Y, Yamamoto K, Abiru H, Nishitani Y, Fukui Y. 2000. Relationship

1105 between cocaine-induced hepatotoxic neurobehavioral \& biochemical changes in mice: the

1106 antidotal effects of buprenorphine. Life Sciences 67:45-52. DOI: $10.1016 / \mathrm{s} 0024-3205(00) 00599-$

$1107 \underline{3}$.

1108 Heard KJ. 2008. Acetylcysteine for Acetaminophen Poisoning. New England Journal of 1109 Medicine 359:285-292. DOI: 10.1056/NEJMct0708278.

1110 Henne-Bruns D, Artwohl J, Broelsch C, Kremer B. 1988. Acetaminophen-induced acute

1111 hepatic failure in pigs: Controversical results to other animal models. Research in Experimental 1112 Medicine 188:463-472. DOI: 10.1007/BF01852004. 
1113 Heymann F, Hamesch K, Weiskirchen R, Tacke F. 2015. The concanavalin A model of acute

1114 hepatitis in mice. Laboratory Animals 49:12-20. DOI: 10.1177/0023677215572841.

1115 Ho DWY, Lam DK, Chen Y-B, To J, Ng IOL, Fan ST. 2002. Galactosamine-induced fulminant

1116 liver failure--observation in a porcine model. Asian Journal of Surgery 25:73-79; discussion 80111781.

1118 Holmin T, Alinder G, Herlin P. 1982. A Microsurgical Method for Total Hepatectomy in the 1119 Rat. European Surgical Research 14:420-427. DOI: $\underline{10.1159 / 000128316 .}$

1120 Horák J, Horký J, Ruzbarský V. 1980. [Temporary ischemia of the liver as a model of acute

1121 hepatic failure in the dog]. Rozhledy V Chirurgii: Mesicnik Ceskoslovenske Chirurgicke 1122 Spolecnosti 59:283-288.

1123 Hung K-C, Yong C-C, Chen Y-S, Eng H-L, Kuo F-Y, Lin C-C, Young T-H, Kobayashi E,

1124 Chen C-L, Wang C-C. 2007. A surgical model of fulminant hepatic failure in rabbits. Liver 1125 International 27:1333-1341. DOI: 10.1111/j.1478-3231.2007.01512.x.

1126 IJtsma AJC, van der Hilst CS, de Boer MT, de Jong KP, Peeters PMJG, Porte RJ, Slooff

1127 MJH. 2009. The clinical relevance of the anhepatic phase during liver transplantation. Liver 1128 Transplantation 15:1050-1055. DOI: $\underline{\text { 10.1002/1t.21791. }}$.

1129 Ilic S, Drmic D, Franjic S, Kolenc D, Coric M, Brcic L, Klicek R, Radic B, Sever M, Djuzel

1130 V, Filipovic M, Djakovic Z, Stambolija V, Blagaic AB, Zoricic I, Gjurasin M, Stupnisek M,

1131 Romic Z, Zarkovic K, Dzidic S, Seiwerth S, Sikiric P. 2011. Pentadecapeptide BPC 157 and its

1132 effects on a NSAID toxicity model: diclofenac-induced gastrointestinal, liver, and encephalopathy

1133 lesions. Life Sciences 88:535-542. DOI: 10.1016/j.1fs.2011.01.015. 
1134 Inderbitzin D, Studer P, Sidler D, Beldi G, Djonov V, Keogh A, Candinas D. 2006.

1135 Regenerative capacity of individual liver lobesin the microsurgical mouse model. Microsurgery

1136 26:465-469. DOI: $10.1002 /$ micr.20271.

1137 Ishiguro S, Takada Y, Gu M, Fukunaga K, Taniguchi H, Seino K, Kawamoto T, Yuzawa K,

1138 Otsuka M, Todoroki T, Fukao K. 2003. Auxiliary partial orthotopic liver transplantation for

1139 fulminant hepatitis: regeneration of the diseased native liver in a pig model1. Transplantation

1140 75:1901-1904. DOI: 10.1097/01.TP.0000065293.75456.08.

1141 Jauregui HO, Mullon CJ, Trenkler D, Naik S, Santangini H, Press P, Muller TE, Solomon

1142 BA. 1995. In vivo evaluation of a hollow fiber liver assist device. Hepatology (Baltimore, Md.)

$114321: 460-469$.

1144 Jedicke N, Struever N, Aggrawal N, Welte T, Manns MP, Malek NP, Zender L,

1145 Janciauskiene S, Wuestefeld T. 2014. Alpha-1-antitrypsin inhibits acute liver failure in mice.

1146 Hepatology 59:2299-2308. DOI: 10.1002/hep.27024.

1147 Joyeux H, Joyeux A, Raoux P, Brissac C, Blanc F, Solassol C. 1977. [Metabolic disorders in

1148 experimental hepatic insufficiency and parenteral feeding]. Annales De L'anesthesiologie

1149 Francaise 18:939-947.

1150 Kalpana K, Ong HS, Soo KC, Tan SY, Raj JP. 1999. An Improved Model of Galactosamine-

1151 Induced Fulminant Hepatic Failure in the Pig. Journal of Surgical Research 82:121-130. DOI:

$1152 \quad \underline{10.1006 / \text { jsre.1998.5420. }}$.

1153 Kanel GC, Cassidy W, Shuster L, Reynolds TB. 1990. Cocaine-induced liver cell injury:

1154 Comparison of morphological features in man and in experimental models. Hepatology 11:646-

1155 651. DOI: 10.1002/hep.1840110418. 
1156 Karvellas CJ, Tillman H, Leung AA, Lee WM, Schilsky ML, Hameed B, Stravitz RT,

1157 McGuire BM, Fix OK. 2016. Acute liver injury and acute liver failure from mushroom poisoning

1158 in North America. Liver International 36:1043-1050. DOI: 10.1111/liv.13080.

1159 Kelly JH, Koussayer T, He D-E, Chong MG, Shang TA, Whisennand HH, Sussman NL.

1160 1992. An improved model of acetaminophen-induced fulminant hepatic failure in dogs.

1161 Hepatology 15:329-335. DOI: 10.1002/hep.1840150225.

1162 Khalili TM, Navarro A, Ting P, Kamohara Y, Arkadopoulos N, Solomon BA, Demetriou

1163 AA, Rozga J. 2001. Bioartificial Liver Treatment Prolongs Survival and Lowers Intracranial

1164 Pressure in Pigs with Fulminant Hepatic Failure. Artificial Organs 25:566-570. DOI:

$1165 \underline{10.1046 / \mathrm{j} .1525-1594.2001 .025007566 . x}$.

1166 Kido M, Watanabe N, Okazaki T, Akamatsu T, Tanaka J, Saga K, Nishio A, Honjo T, Chiba

1167 T. 2008. Fatal autoimmune hepatitis induced by concurrent loss of naturally arising regulatory $\mathrm{T}$

1168 cells and PD-1-mediated signaling. Gastroenterology 135:1333-1343. DOI:

1169 10.1053/j.gastro.2008.06.042.

1170 Kim HJ, Bruckner JV, Dallas CE, Gallo JM. 1990. Effect of dosing vehicles on the

1171 pharmacokinetics of orally administered carbon tetrachloride in rats. Toxicology and Applied

1172 Pharmacology 102:50-60. DOI: 10.1016/0041-008X(90)90082-6.

1173 Kim J, Chang D-Y, Shin E-C. 2014. T cell-mediated immunopathologic mechanism of liver

1174 injury in acute viral hepatitis (HUM8P.336). The Journal of Immunology 192:185.11-185.11.

1175 Koblihová E, Mrázová I, Vernerová Z, Ryska M. 2014. Acute liver failure induced by

1176 thioacetamide: selection of optimal dosage in Wistar and Lewis rats. Physiological Research

1177 63:491-503. DOI: $\underline{\text { 10.33549/physiolres.932690. }}$. 
1178 Koch DG, Speiser JL, Durkalski V, Fontana RJ, Davern T, McGuire B, Stravitz RT, Larson

1179 AM, Liou I, Fix O, Schilsky ML, McCashland T, Hay JE, Murray N, Shaikh OS, Ganger D,

1180 Zaman A, Han SB, Chung RT, Brown RS, Munoz S, Reddy KR, Rossaro L, Satyanarayana

1181 R, Hanje AJ, Olson J, Subramanian RM, Karvellas C, Hameed B, Sherker AH, Lee WM,

1182 Reuben A. 2017. The Natural History of Severe Acute Liver Injury. The American Journal of

1183 Gastroenterology 112:1389-1396. DOI: 10.1038/ajg.2017.98.

1184 Kogure K, Ishizaki M, Nemoto M, Kuwano H, Makuuchi M. 1999. A comparative study of the 1185 anatomy of rat and human livers. Journal of Hepato-Biliary-Pancreatic Surgery 6:171-175. DOI:

$1186 \quad 10.1007 / \mathrm{s} 005340050101$.

1187 Kučera O, Roušar T, Staňková P, Haňáčková L, Lotková H, Podhola M, Červinková Z. 2012.

1188 Susceptibility of rat non-alcoholic fatty liver to the acute toxic effect of acetaminophen. Journal

1189 of Gastroenterology and Hepatology 27:323-330. DOI: 10.1111/j.1440-1746.2011.06807.x.

1190 Laqueur GL, Mickelsen O, Whiting MG, Kurland LT. 1963. Carcinogenic properties of nuts

1191 from Cycas circinalis 1. indigenous to Guam. Journal of the National Cancer Institute 31:919-951.

1192 Lashkevich VA, Koroleva GA, Tereshkina NV, Lukashev AN, Grigor'eva LV, Titova IP.

1193 1996. [Superacute lethal liver necrosis in monkeys infected with highly pathogenic variants of

1194 enteroviruses (ECHO 11 and ECHO 19 viruses)]. Voprosy Virusologii 41:198-206.

1195 Lee WM, Squires RH, Nyberg SL, Doo E, Hoofnagle JH. 2008. Acute liver failure: Summary

1196 of a workshop. Hepatology (Baltimore, Md.) 47:1401-1415. DOI: 10.1002/hep.22177.

1197 Lehmann K, Tschuor C, Rickenbacher A, Jang J, Oberkofler CE, Tschopp O, Schultze SM,

1198 Raptis DA, Weber A, Graf R, Humar B, Clavien P. 2012. Liver Failure After Extended

1199 Hepatectomy in Mice Is Mediated by a p21-Dependent Barrier to Liver Regeneration.

1200 Gastroenterology 143:1609-1619.e4. DOI: 10.1053/j.gastro.2012.08.043. 
1201 Leon LAA, Marchevsky RS, Gaspar AMC, Garcia R de CNC, Almeida AJ de, Pelajo-

1202 Machado M, Castro TX de, Nascimento JP do, Brown KE, Pinto MA. 2016. Cynomolgus

1203 monkeys (Macaca fascicularis) experimentally infected with B19V and hepatitis A virus: no

1204 evidence of the co-infection as a cause of acute liver failure. Memórias do Instituto Oswaldo Cruz

1205 111:258-266. DOI: $\underline{\text { 10.1590/0074-02760160013. }}$.

1206 Li J, Zhang L, Xin J, Jiang L, Li J, Zhang T, Jin L, Li J, Zhou P, Hao S, Cao H, Li L. 2012.

1207 Immediate intraportal transplantation of human bone marrow mesenchymal stem cells prevents 1208 death from fulminant hepatic failure in pigs. Hepatology 56:1044-1052. DOI: 10.1002/hep.25722.

1209 Li Y, Togashi Y, Sato S, Emoto T, Kang JH, Takeichi N, Kobayashi H, Kojima Y, Une Y,

1210 Uchino J. 1991. Spontaneous hepatic copper accumulation in Long-Evans Cinnamon rats with

1211 hereditary hepatitis. A model of Wilson's disease. The Journal of Clinical Investigation 87:1858-

1212 1861. DOI: $\underline{10.1172 / \mathrm{JCI} 115208 .}$.

1213 Li Y, Wu Q, Wang Y, Weng C, He Y, Gao M, Yang G, Li L, Chen F, Shi Y, Amiot BP,

1214 Nyberg SL, Bao J, Bu H. 2018. Novel spheroid reservoir bioartificial liver improves survival of

1215 nonhuman primates in a toxin-induced model of acute liver failure. Theranostics 8:5562-5574.

1216 DOI: $\underline{10.7150 / \text { thno.26540. }}$.

1217 Lindquist ME, Zeng X, Altamura LA, Daye SP, Delp KL, Blancett C, Coffin KM, Koehler

1218 JW, Coyne S, Shoemaker CJ, Garrison AR, Golden JW. Exploring Crimean-Congo

1219 Hemorrhagic Fever Virus-Induced Hepatic Injury Using Antibody-Mediated Type I Interferon

1220 Blockade in Mice. Journal of Virology 92:e01083-18. DOI: 10.1128/JVI.01083-18.

1221 Liu L, Zhao Y, Lin Y, Zhang R, Luo S, Ye P, Luo M. 2019. The antagonistic effect of tamoxifen

1222 against d-galactosamine/lipopolysaccharide-induced acute liver failure is associated with 
1223 reactivation of hepatic nuclear factor- $\kappa$ B. Immunopharmacology and Immunotoxicology 41:192-

1224 198. DOI: $\underline{10.1080 / 08923973.2019 .1569044 .}$

1225 Longo CR, Patel VI, Shrikhande GV, Scali ST, Csizmadia E, Daniel S, Sun DW, Grey ST,

1226 Arvelo MB, Ferran C. 2005. A20 protects mice from lethal radical hepatectomy by promoting

1227 hepatocyte proliferation via a p21waf1-dependent mechanism. Hepatology 42:156-164. DOI:

1228 10.1002/hep.20741.

1229 Loukopoulos I, Sfiniadakis I, Pillai A, Konstantoulakis M, Androulakis G, Bonatsos V,

1230 Zografos G, Papalois A. 2014. Mycophenolate Mofetil and Sirolimus in Hepatocyte

1231 Transplantation in an Experimental Model of Toxic Acute Liver Failure. Journal of Investigative

1232 Surgery 27:205-213. DOI: 10.3109/08941939.2013.879967.

1233 Lu J, Jones AD, Harkema JR, Roth RA, Ganey PE. 2012. Amiodarone exposure during modest

1234 inflammation induces idiosyncrasy-like liver injury in rats: role of tumor necrosis factor-alpha.

1235 Toxicological Sciences: An Official Journal of the Society of Toxicology 125:126-133. DOI:

$1236 \quad \underline{10.1093 / \text { toxsci/kfr266. }}$.

1237 Luyendyk JP, Maddox JF, Cosma GN, Ganey PE, Cockerell GL, Roth RA. 2003. Ranitidine

1238 Treatment during a Modest Inflammatory Response Precipitates Idiosyncrasy-Like Liver Injury in

1239 Rats. Journal of Pharmacology and Experimental Therapeutics 307:9-16. DOI:

$1240 \quad$ 10.1124/jpet.103.054288.

1241 Lv H, Hong L, Tian Y, Yin C, Zhu C, Feng H. 2019. Corilagin alleviates acetaminophen-

1242 induced hepatotoxicity via enhancing the AMPK/GSK3 $\beta$-Nrf2 signaling pathway. Cell

1243 Communication and Signaling 17:2. DOI: 10.1186/s12964-018-0314-2.

1244 Machaidze Z, Yeh H, Wei L, Schuetz C, Carvello M, Sgroi A, Smith RN, Schuurman H-J,

1245 Sachs DH, Morel P, Markmann JF, Bühler LH. 2017. Testing of microencapsulated porcine 
1246 hepatocytes in a new model of fulminant liver failure in baboons. Xenotransplantation 24:e12297.

1247 DOI: $10.1111 /$ xen.12297.

1248 Madrahimov N, Dirsch O, Broelsch C, Dahmen U. 2006. Marginal Hepatectomy in the Rat:

1249 From Anatomy to Surgery. Annals of Surgery 244:89-98. DOI:

$1250 \quad$ 10.1097/01.sla.0000218093.12408.0f.

1251 Mahmoud YI, Mahmoud AA. 2016. Role of nicotinamide (vitamin B3) in acetaminophen-

1252 induced changes in rat liver: Nicotinamide effect in acetaminophen-damged liver. Experimental 1253 and Toxicologic Pathology 68:345-354. DOI: 10.1016/j.etp.2016.05.003.

1254 Makino H, Togo S, Kubota T, Morioka D, Morita T, Kobayashi T, Tanaka K, Shimizu T,

1255 Matsuo K, Nagashima Y, Shimada H. 2005. A Good Model of Hepatic Failure after Excessive 1256 Hepatectomy in Mice. Journal of Surgical Research 127:171-176. DOI:

$1257 \quad 10.1016 /$ j.jss.2005.04.029.

1258 Malassagne B, Ferret PJ, Hammoud R, Tulliez M, Bedda S, Trébéden H, Jaffray P,

1259 Calmus Y, Weill B, Batteux F. 2001. The superoxide dismutase mimetic MnTBAP prevents

1260 Fas-induced acute liver failure in the mouse. Gastroenterology 121:1451-1459. DOI:

1261 10.1053/gast.2001.29590.Manka P, Verheyen J, Gerken G, Canbay A. 2016. Liver Failure

1262 due to Acute Viral Hepatitis (A-E). Visceral Medicine 32:80-85. DOI: 10.1159/000444915.

1263 Mark AL, Sun Z, Warren DS, Lonze BE, Knabel MK, Williams GMM, Locke JE, 1264 Montgomery RA, Cameron AM. 2010. Stem Cell Mobilization Is Life Saving in an Animal 1265 Model of Acute Liver Failure. Annals of Surgery 252:591-596. DOI: $1266 \quad 10.1097 /$ SLA.0b013e3181f4e479. 
1267 Martin JP, Chen W, Koehren F, Pereira CA. 1994. The virulence of mouse hepatitis virus 3, as

1268 evidenced by permissivity of cultured hepatic cells toward escape mutants. Research in Virology

1269 145:297-302. DOI: 10.1016/s0923-2516(07)80034-3.

1270 Matkowskyj KA, Marrero JA, Carroll RE, Danilkovich AV, Green RM, Benya RV. 1999.

1271 Azoxymethane-induced fulminant hepatic failure in C57BL/6J mice: characterization of a new

1272 animal model. American Journal of Physiology-Gastrointestinal and Liver Physiology 277:G455-

1273 G462. DOI: 10.1152/ajpgi.1999.277.2.G455.

1274 McGill MR, Williams CD, Xie Y, Ramachandran A, Jaeschke H. 2012. Acetaminophen-

1275 induced liver injury in rats and mice: comparison of protein adducts, mitochondrial dysfunction,

1276 and oxidative stress in the mechanism of toxicity. Toxicology and Applied Pharmacology

1277 264:387-394. DOI: $10.1016 /$ j.taap.2012.08.015.

1278 McGill MR, Du K, Xie Y, Bajt ML, Ding W-X, Jaeschke H. 2015. The role of the c-Jun N-

1279 terminal kinases $1 / 2$ and receptor-interacting protein kinase 3 in furosemide-induced liver injury.

1280 Xenobiotica 45:442-449. DOI: 10.3109/00498254.2014.986250.

1281 McGill MR, Jaeschke H. 2019. Animal models of drug-induced liver injury. Biochimica Et

1282 Biophysica Acta. Molecular Basis of Disease 1865:1031-1039. DOI:

$1283 \quad 10.1016 / \mathrm{j}$. bbadis.2018.08.037.

1284 Meier M, Andersen KJ, Knudsen AR, Nyengaard JR, Hamilton-Dutoit S, Mortensen FV.

1285 2016. Liver regeneration is dependent on the extent of hepatectomy. Journal of Surgical Research

1286 205:76-84. DOI: $\underline{\text { 10.1016/j.jss.2016.06.020. }}$

1287 Metushi IG, Hayes MA, Uetrecht J. 2015. Treatment of PD-1-/- mice with amodiaquine and

1288 anti-CTLA4 leads to liver injury similar to idiosyncratic liver injury in patients. Hepatology

1289 61:1332-1342. DOI: 10.1002/hep.27549. 
1290 Miller DJ, Hickman R, Fratter R, Terblanche J, Saunders SJ. 1976. An animal model of

1291 fulminant hepatic failure: a feasibility study. Gastroenterology 71:109-113.

1292 Miranda AS de, Rodrigues DH, Vieira LB, Lima CX, Rachid MA, Vidigal PVT, Gomez MV,

1293 Reis HJ dos, Guatimosim C, Teixeira AL. 2010. A thioacetamide-induced hepatic

1294 encephalopathy model in C57BL/6 mice: a behavioral and neurochemical study. Arquivos de

1295 Neuro-Psiquiatria 68:597-602. DOI: 10.1590/S0004-282X2010000400022.

1296 Mitchell JR, Jollow DJ, Potter WZ, Gillette JR, Brodie BB. 1973a. Acetaminophen-induced

1297 hepatic necrosis. IV. Protective role of glutathione. The Journal of Pharmacology and 1298 Experimental Therapeutics 187:211-217.

1299 Mitchell JR, Jollow DJ, Potter WZ, Davis DC, Gillette JR, Brodie BB. 1973b. Acetaminophen-

1300 induced hepatic necrosis. I. Role of drug metabolism. The Journal of Pharmacology and 1301 Experimental Therapeutics 187:185-194.

1302 Mizuguchi Y, Yokomuro S, Mishima T, Arima Y, Shimizu T, Kawahigashi Y, Takizawa T, 1303 Tajiri T. 2007. Therapeutic Use of Short Hairpin RNA in Acute Liver Failure. Journal of Nippon 1304 Medical School 74:74-76. DOI: 10.1272/jnms.74.74.

1305 Mladenović D, Radosavljević T, Hrnčić D, Rašić-Marković A, Puškaš N, Maksić N, Djuric

1306 D, Stanojlović O. 2012. Behavioral and electroencephalographic manifestations of thioacetamide-

1307 induced encephalopathy in rats. Canadian Journal of Physiology and Pharmacology 90:1219-

1308 1227. DOI: $10.1139 / \mathrm{y} 2012-088$.

1309 Moharib MN, Waldemar LO, Mikhail NE, Nossier MMF, Atta SAH, Saber MA. 2014.

1310 Allogenic Hepatocyte Transplantation Inimmunomodulated Lewis Rats with Acute Liver

1311 Insufficiency following Hepatectomy. Journal of the Egyptian Society of Parasitology 240:1-8.

1312 DOI: $\underline{10.12816 / 0006462 .}$ 
1313 Mossanen J, Tacke F. 2015. Acetaminophen-induced acute liver injury in mice. Laboratory

1314 Animals 49:30-36. DOI: $\underline{10.1177 / 0023677215570992 .}$

1315 Murira A, Lamarre A. 2016. Type-I Interferon Responses: From Friend to Foe in the Battle

1316 against Chronic Viral Infection. Frontiers in Immunology 7:609. DOI:

$1317 \quad \underline{10.3389 / \text { fimmu.2016.00609. }}$.

1318 Nardo B, Tsivian M, Neri F, Piras G, Pariali M, Bertelli R, Cavallari G. 2008. Extracorporeal

1319 portal vein oxygenation improves outcome of acute liver failure in swine. Transplantation

1320 Proceedings 40:2046-2048. DOI: 10.1016/j.transproceed.2008.05.026.

1321 Navarro-Alvarez N, Machaidze Z, Schuetz C, Zhu A, Liu W, Shah JA, Vagefi PA, Elias N,

1322 Buhler L, Sachs DH, Markmann JF, Yeh H. 2018. Xenogeneic Heterotopic Auxiliary Liver

1323 transplantation (XHALT) promotes native liver regeneration in a Post-Hepatectomy Liver failure

1324 model. PLOS ONE 13:e0207272. DOI: 10.1371/journal.pone.0207272.

1325 Newsome PN, Henderson NC, Nelson LJ, Dabos C, Filippi C, Bellamy C, Howie F, Clutton

1326 RE, King T, Lee A, Hayes PC, Plevris JN. 2010. Development of an invasively monitored

1327 porcine model of acetaminophen-induced acute liver failure. BMC Gastroenterology 10:34. DOI:

$1328 \quad \underline{10.1186 / 1471-230 X-10-34 .}$

1329 Nishimuta H, Nakagawa T, Nomura N, Yabuki M. 2013. Species differences in hepatic and

1330 intestinal metabolic activities for 43 human cytochrome P450 substrates between humans and rats

1331 or dogs. Xenobiotica; the Fate of Foreign Compounds in Biological Systems 43:948-955. DOI:

$1332 \quad \underline{10.3109 / 00498254.2013 .787155 .}$.

1333 Nyberg SL, Shirabe K, Peshwa MV, Sielaff TD, Crotty PL, Mann HJ, Remmel RP, Payne

1334 WD, Hu WS, Cerra FB. 1993. Extracorporeal application of a gel-entrapment, bioartificial liver: 
1335 demonstration of drug metabolism and other biochemical functions. Cell Transplantation 2:441-

1336 452. DOI: $\underline{10.1177 / 096368979300200602}$.

1337 Nyberg SL, Cerra FB, Gruetter R. 1998. Brain lactate by magnetic resonance spectroscopy

1338 during fulminant hepatic failure in the dog. Liver Transplantation and Surgery 4:158-165. DOI:

$1339 \quad 10.1002 / 1 \mathrm{t} .500040203$.

1340 Nykonenko A, Vávra P, Zonča P. 2017. Anatomic Peculiarities of Pig and Human Liver.

1341 Experimental and Clinical Transplantation: Official Journal of the Middle East Society for Organ

1342 Transplantation 15:21-26.

1343 Ogata T, Yamashita K, Horiuchi H, Okuda K, Todo S. 2008. A novel tumor necrosis factor- $\alpha$

1344 suppressant, ONO-SM362, prevents liver failure and promotes liver regeneration after extensive

1345 hepatectomy. Surgery 143:545-555. DOI: 10.1016/j.surg.2007.11.010.

1346 O'Grady JG, Schalm SW, Williams R. 1993. Acute liver failure: redefining the syndromes.

1347 Lancet (London, England) 342:273-275. DOI: 10.1016/0140-6736(93)91818-7.

1348 Ohashi N, Hori T, Chen F, Jermanus S, Nakao A, Uemoto S, Nguyen JH. 2013. Matrix

1349 metalloproteinase-9 in the initial injury after hepatectomy in mice. World Journal of

1350 Gastroenterology 19:3027-3042. DOI: 10.3748/wjg.v19.i20.3027.

1351 Pagano D, di Francesco F, Echeverri GJ, de Martino M, Ricotta C, Occhipinti G, Pagano V,

1352 Oliva E, Minervini MI, Gridelli BG, Spada M. 2012. Development of a Standardized Model for

1353 Liver Failure in Pigs: Anatomopathophysiologic Findings After Extended Liver Resection.

1354 Transplantation Proceedings 44:2029-2032. DOI: 10.1016/j.transproceed.2012.06.009.

1355 Panatto JP, Jeremias IC, Ferreira GK, Ramos ÂC, Rochi N, Gonçalves CL, Daufenbach JF,

1356 Jeremias GC, Carvalho-Silva M, Rezin GT, Scaini G, Streck EL. 2011. Inhibition of 
1357 mitochondrial respiratory chain in the brain of rats after hepatic failure induced by acetaminophen.

1358 Molecular and Cellular Biochemistry 350:149-154. DOI: 10.1007/s11010-010-0689-x.

1359 Parker ZM, Pasieka TJ, Parker GA, Leib DA. Immune- and Nonimmune-Compartment-

1360 Specific Interferon Responses Are Critical Determinants of Herpes Simplex Virus-Induced

1361 Generalized Infections and Acute Liver Failure. Journal of Virology 90:10789-10799. DOI:

$1362 \underline{10.1128 / J V I .01473-16 .}$

1363 Rahman TM, Hodgson HJF. 2000. Animal models of acute hepatic failure. International Journal

1364 of Experimental Pathology 81:145-157. DOI: 10.1046/j.1365-2613.2000.00144.x.

1365 Rahman TM, Selden AC, Hodgson HJF. 2002. A Novel Model of Acetaminophen-Induced

1366 Acute Hepatic Failure in Rabbits. Journal of Surgical Research 106:264-272. DOI:

$1367 \underline{10.1006 / \text { jsre.2002.6476. }}$.

1368 Ramachandran A, Jaeschke H. 2019. Acetaminophen Hepatotoxicity. Seminars in Liver Disease

1369 39:221-234. DOI: $\underline{\text { 10.1055/s-0039-1679919. }}$

1370 Ramsi Siaj VS, Ppeler H-US, Hler AZ. 2012. Dietary copper triggers onset of fulminant hepatitis

1371 in the Long-Evans cinnamon rat model. World Journal of Gastroenterology 18:5542-5550. DOI:

$1372 \quad$ 10.3748/wjg.v18.i39.5542.

1373 Robinson A. 2018. Did Einstein really say that? Nature 557:30-30. DOI: 10.1038/d41586-018-

$1374 \quad \underline{05004-4}$.

1375 Rogers AB, Dintzis RZ. 2018. 13 - Hepatobiliary System. In: Treuting PM, Dintzis SM, Montine

1376 KS eds. Comparative Anatomy and Histology (Second Edition). San Diego: Academic Press, 229-

1377 239. DOI: $\underline{10.1016 / \mathrm{B} 978-0-12-802900-8.00013-0 .}$. 
1378 Roth-Cross JK, Bender SJ, Weiss SR. 2008. Murine Coronavirus Mouse Hepatitis Virus Is

1379 Recognized by MDA5 and Induces Type I Interferon in Brain Macrophages/Microglia. Journal of

1380 Virology 82:9829-9838. DOI: 10.1128/JVI.01199-08.

1381 Rozga J, Jeppsson B, Bengmark S, Demetriou AA. 1992. A simple two-stage technique of total

1382 hepatectomy in the rat. Journal of Surgical Research 52:46-49. DOI: 10.1016/0022-

1383 4804(92)90277-7.

1384 Rubin JB, Hameed B, Gottfried M, Lee WM, Sarkar M. 2018. Acetaminophen-induced Acute

1385 Liver Failure Is More Common and More Severe in Women. Clinical Gastroenterology and

1386 Hepatology 16:936-946. DOI: 10.1016/j.cgh.2017.11.042.

1387 Sahay P, Jain K, Sinha P, Das B, Mishra A, Kesarwani A, Sahu P, Mohan KV, Kumar MJM,

1388 Nagarajan P, Upadhyay P. 2019. Generation of a Rat Model of Acute Liver Failure by

1389 Combining 70\% Partial Hepatectomy and Acetaminophen. JoVE (Journal of Visualized

1390 Experiments):e60146. DOI: $\underline{10.3791 / 60146 .}$

1391 Sánchez-Campos S, Alvarez M, Culebras JM, Gonzalez-Gallego J, Tuñón MJ. 2004.

1392 Pathogenic molecular mechanisms in an animal model of fulminant hepatic failure: rabbit

1393 hemorrhagic viral disease. The Journal of Laboratory and Clinical Medicine 144:215-222. DOI:

1394 10.1016/j.lab.2004.07.006.

1395 Sang J-F, Shi X-L, Han B, Huang T, Huang X, Ren H-Z, Ding Y-T. 2016. Intraportal

1396 mesenchymal stem cell transplantation prevents acute liver failure through promoting cell

1397 proliferation and inhibiting apoptosis. Hepatobiliary \& Pancreatic Diseases International 15:602-

1398 611. DOI: $\underline{10.1016 / \mathrm{S} 1499-3872(16) 60141-8 .}$

1399 San-Miguel B, Alvarez M, Culebras JM, González-Gallego J, Tuñón MJ. 2006. N-acetyl-

1400 cysteine protects liver from apoptotic death in an animal model of fulminant hepatic failure. 
1401 Apoptosis: An International Journal on Programmed Cell Death 11:1945-1957. DOI: $1402 \quad \underline{10.1007 / \mathrm{s} 10495-006-0090-0 .}$.

1403 Santi L, Maggioli C, Mastroroberto M, Tufoni M, Napoli L, Caraceni P. 2012. Acute Liver 1404 Failure Caused by Amanita phalloides Poisoning. International Journal of Hepatology 1405 2012:e487480. DOI: $\underline{10.1155 / 2012 / 487480 .}$

1406 Sasaki E, Iida A, Oda S, Tsuneyama K, Fukami T, Nakajima M, Yokoi T. 2016. Pathogenetic 1407 analyses of carbamazepine-induced liver injury in F344 rats focused on immune- and 1408 inflammation-related factors. Experimental and Toxicologic Pathology: Official Journal of the 1409 Gesellschaft Fur Toxikologische Pathologie 68:27-38. DOI: 10.1016/j.etp.2015.09.004.

1410 Sawant SP, Dnyanmote AV, Warbritton A, Latendresse JR, Mehendale HM. 2006. Type 2 1411 diabetic rats are sensitive to thioacetamide hepatotoxicity. Toxicology and Applied Pharmacology 1412 211:221-232. DOI: 10.1016/j.taap.2005.07.019.

1413 Schuppan D, Afdhal NH. 2008. Liver cirrhosis. Lancet (London, England) 371:838-851. DOI: $1414 \quad 10.1016 / \mathrm{S} 0140-6736(08) 60383-9$.

1415 Seok J, Warren HS, Cuenca AG, Mindrinos MN, Baker HV, Xu W, Richards DR, 1416 McDonald-Smith GP, Gao H, Hennessy L, Finnerty CC, López CM, Honari S, Moore EE, 1417 Minei JP, Cuschieri J, Bankey PE, Johnson JL, Sperry J, Nathens AB, Billiar TR, West MA, 1418 Jeschke MG, Klein MB, Gamelli RL, Gibran NS, Brownstein BH, Miller-Graziano C, 1419 Calvano SE, Mason PH, Cobb JP, Rahme LG, Lowry SF, Maier RV, Moldawer LL, Herndon 1420 DN, Davis RW, Xiao W, Tompkins RG, Inflammation and Host Response to Injury, Large 1421 Scale Collaborative Research Program. 2013. Genomic responses in mouse models poorly 1422 mimic human inflammatory diseases. Proceedings of the National Academy of Sciences of the 1423 United States of America 110:3507-3512. DOI: 10.1073/pnas.1222878110. 
1424 Sharma AD, Narain N, Händel E-M, Iken M, Singhal N, Cathomen T, Manns MP, Schöler

1425 HR, Ott M, Cantz T. 2011. MicroRNA-221 regulates FAS-induced fulminant liver failure.

1426 Hepatology 53:1651-1661. DOI: 10.1002/hep.24243.

1427 Shaw PJ, Hopfensperger MJ, Ganey PE, Roth RA. 2007. Lipopolysaccharide and trovafloxacin

1428 coexposure in mice causes idiosyncrasy-like liver injury dependent on tumor necrosis factor-alpha.

1429 Toxicological Sciences: An Official Journal of the Society of Toxicology 100:259-266. DOI:

$1430 \quad \underline{10.1093 / \text { toxsci/kfm218. }}$.

1431 Shen Y, Wang Y, Shi Y, Tian H, Zhu Q, Ding F. 2020. Development of liposome as a novel

1432 adsorbent for artificial liver support system in liver failure. Journal of Liposome Research 30:246-

1433 254. DOI: $\underline{10.1080 / 08982104.2019 .1630644 .}$

1434 Shen Z, Wang Y, Su Z, Kou R, Xie K, Song F. 2018. Activation of p62-keap1-Nrf2 antioxidant

1435 pathway in the early stage of acetaminophen-induced acute liver injury in mice. Chemico-

1436 Biological Interactions 282:22-28. DOI: 10.1016/j.cbi.2018.01.008.

1437 Shi D, Zhang J, Zhou Q, Xin J, Jiang J, Jiang L, Wu T, Li J, Ding W, Li J, Sun S, Li J, Zhou

1438 N, Zhang L, Jin L, Hao S, Chen P, Cao H, Li M, Li L, Chen X, Li J. 2017. Quantitative

1439 evaluation of human bone mesenchymal stem cells rescuing fulminant hepatic failure in pigs. Gut

1440 66:955-964. DOI: 10.1136/gutjnl-2015-311146.

1441 Sielaff TD, Hu MY, Rollins MD, Bloomer JR, Amiot B, Hu WS, Cerra FB. 1995. An

1442 anesthetized model of lethal canine galactosamine fulminant hepatic failure. Hepatology

1443 (Baltimore, Md.) 21:796-804.

1444 Skawran S, Palmes D, Budny T, Bahde R, Stratmann U, Spiegel HU. 2003. Development and

1445 evaluation of an experimental model for investigating the pathogenesis and therapeutic strategies 
1446 of acute liver failure. Transplantation Proceedings 35:3142-3146. DOI:

$1447 \quad$ 10.1016/j.transproceed.2003.10.022.

1448 Stan FG. 2018. Comparative Study of the Liver Anatomy in the Rat, Rabbit, Guinea Pig and

1449 Chinchilla. Bulletin of University of Agricultural Sciences and Veterinary Medicine Cluj-Napoca.

1450 Veterinary Medicine 75:33-40. DOI: 10.15835/buasvmcn-vm:002717.

1451 Starzl TE, Porter KA, Francavilla A. 1983. The Eck fistula in animals and humans. Current

1452 Problems in Surgery 20:687-752. DOI: 10.1016/s0011-3840(83)80010-0.

1453 Stravitz RT, Lee WM. 2019. Acute liver failure. Lancet (London, England) 394:869-881. DOI:

$1454 \quad 10.1016 / \mathrm{S} 0140-6736(19) 31894-\mathrm{X}$.

1455 Strom SC, Davila J, Grompe M. 2010. Chimeric Mice with Humanized Liver: Tools for the

1456 Study of Drug Metabolism, Excretion, and Toxicity. Methods in molecular biology (Clifton, N.J.)

1457 640:491-509. DOI: $10.1007 / 978-1-60761-688-7 \quad 27$.

1458 Sugawara N, Sugawara C, Katakura M, Takahashi H, Mori M. 1991. Harmful effect of

1459 administration of copper on LEC rats. Research Communications in Chemical Pathology and

1460 Pharmacology 73:289-297.

1461 Swindle MM. Liver and Biliary System. In: Swindle MM, Smith AC, eds. Swine in the

1462 Laboratory. $3^{\text {rd }}$ ed. Boca Raton: CRC Press; 2016. p. 135-154.

1463 Tadokoro T, Morishita A, Sakamoto T, Fujihara S, Fujita K, Mimura S, Oura K, Nomura

1464 T, Tani J, Yoneyama H, Iwama H, Himoto T, Niki T, Hirashima M, Masaki T. 2017.

1465 Galectin-9 ameliorates fulminant liver injury. Molecular Medicine Reports 16:36-42. DOI:

$1466 \quad 10.3892 / \mathrm{mmr} .2017 .6606$.

1467 Takada Y, Ishiguro S, Fukunaga K, Gu M, Taniguchi H, Seino K-I, Yuzawa K, Otsuka M,

1468 Todoroki T, Fukao K. 2001. Increased intracranial pressure in a porcine model of fulminant 
1469 hepatic failure using amatoxin and endotoxin. Journal of Hepatology 34:825-831. DOI:

$1470 \quad 10.1016 / \mathrm{S} 0168-8278(01) 00003-4$.

1471 Takamoto S, Nakamura K, Yoneda M, Makino I. 2003. Gender-related differences in

1472 concanavalin A-induced liver injury and cytokine production in mice. Hepatology Research

1473 27:221-229. DOI: 10.1016/S1386-6346(03)00263-8.

1474 Takamura M, Matsuda Y, Yamagiwa S, Tamura Y, Honda Y, Suzuki K, Ichida T, Aoyagi

1475 Y. 2007. An inhibitor of c-Jun NH2-terminal kinase, SP600125, protects mice from d-

1476 galactosamine/lipopolysaccharide-induced hepatic failure by modulating BH3-only proteins. Life

1477 Sciences 80:1335-1344. DOI: 10.1016/j.1fs.2006.12.034.

1478 Terada K, Sugiyama T. 1999. The Long-Evans Cinnamon rat: An animal model for Wilson's

1479 disease. Pediatrics International 41:414-418. DOI: 10.1046/j.1442-200x.1999.01089.x.

1480 Terblanche J, Hickman R. 1991. Animal models of fulminant hepatic failure. Digestive Diseases

1481 and Sciences 36:770-774. DOI: 10.1007/BF01311235.

1482 Thiel C, Thiel K, Etspueler A, Morgalla MH, Rubitschek S, Schmid S, Steurer W,

1483 Königsrainer A, Schenk M. 2011. A Reproducible Porcine Model of Acute Liver Failure Induced

1484 by Intrajejunal Acetaminophen Administration. European Surgical Research 46:118-126. DOI:

$1485 \quad 10.1159 / 000323411$.

1486 Torres S, Baulies A, Insausti-Urkia N, Alarcón-Vila C, Fucho R, Solsona-Vilarrasa E, Núñez

1487 S, Robles D, Ribas V, Wakefield L, Grompe M, Lucena MI, Andrade RJ, Win S, Aung TA,

1488 Kaplowitz N, García-Ruiz C, Fernández-Checa JC. 2019. Endoplasmic Reticulum Stress-

1489 Induced Upregulation of STARD1 Promotes Acetaminophen-Induced Acute Liver Failure.

1490 Gastroenterology 157:552-568. DOI: 10.1053/j.gastro.2019.04.023. 
1491 Tsai M-S, Chien C-C, Lin T-H, Liu C-C, Liu RH, Su H-L, Chiu Y-T, Wang S-H. 2015.

1492 Galangin Prevents Acute Hepatorenal Toxicity in Novel Propacetamol-Induced Acetaminophen-

1493 Overdosed Mice. Journal of Medicinal Food 18:1187-1197. DOI: 10.1089/jmf.2014.3328.

1494 Tuñon MJ, San Miguel B, Crespo I, Riezu-Boj JI, Larrea E, Álvarez M, González I, Bustos

1495 M, González-Gallego J, Prieto J. 2011. Cardiotrophin-1 Promotes a High Survival Rate in

1496 Rabbits with Lethal Fulminant Hepatitis of Viral Origin. Journal of Virology 85:13124-13132.

1497 DOI: 10.1128/JVI.05725-11.Turner PV, Brabb T, Pekow C, Vasbinder MA. 2011.

1498 Administration of Substances to Laboratory Animals: Routes of Administration and Factors to

1499 Consider. Journal of the American Association for Laboratory Animal Science : JAALAS

$1500 \quad 50: 600-613$.

1501 Vogt BL, Richie JP. 1993. Fasting-induced depletion of glutathione in the aging mouse.

1502 Biochemical Pharmacology 46:257-263. DOI: 10.1016/0006-2952(93)90412-P.

1503 Vons C, Beaudoin S, Helmy N, Dagher I, Weber A, Franco D. 2009. First description of the

1504 surgical anatomy of the cynomolgus monkey liver. American Journal of Primatology 71:400-408.

1505 DOI: 10.1002/ajp.20667.

1506 Walker RM, Massey TE, McElligott TF, Racz WJ. 1982. Acetaminophen toxicity in fed and

1507 fasted mice. Canadian Journal of Physiology and Pharmacology 60:399-404. DOI: 10.1139/y82-

$1508 \underline{058}$.

1509 Wallace M, Hamesch K, Lunova M, Kim Y, Weiskirchen R, Strnad P, Friedman S. 2015.

1510 Standard Operating Procedures in Experimental Liver Research: Thioacetamide model in mice

1511 and rats. Laboratory Animals 49:21-29. DOI: $10.1177 / 0023677215573040$.

1512 Waly MI, Al-Rawahi AS, Al Riyami M, Al-Kindi MA, Al-Issaei HK, Farooq SA, Al-Alawi

1513 A, Rahman MS. 2014. Amelioration of azoxymethane induced-carcinogenesis by reducing 
1514 oxidative stress in rat colon by natural extracts. BMC Complementary and Alternative Medicine

1515 14:60. DOI: $\underline{10.1186 / 1472-6882-14-60 .}$

1516 Waly MI, Al-Alawi AA, Al-Marhoobi IM, Rahman MS. 2016. Red Seaweed (Hypnea Bryodies

1517 and Melanothamnus Somalensis) Extracts Counteracting Azoxymethane-Induced Hepatotoxicity

1518 in Rats. Asian Pacific Journal of Cancer Prevention 17:5071-5074. DOI:

1519 10.22034/APJCP.2016.17.12.5071.

1520 Wang J, Cao X, Zhao J, Zhao H, Wei J, Li Q, Qi X, Yang Z, Wang L, Zhang H, Bai L, Wu

1521 Z, Zhao L, Hong Z, Yin Z. 2017. Critical roles of conventional dendritic cells in promoting T

1522 cell-dependent hepatitis through regulating natural killer $\mathrm{T}$ cells. Clinical \& Experimental

1523 Immunology 188:127-137. DOI: $\underline{10.1111 / \text { cei.12907. }}$

1524 Wang W, Lu H, Lu X, Wang D, Wang Z, Dai W, Wang J, Liu P. 2018. Effect of tumor necrosis

1525 factor- $\alpha$ on the expression of the ammonia transporter Rhcg in the brain in mice with acute liver

1526 failure. Journal of Neuroinflammation 15:234. DOI: 10.1186/s12974-018-1264-8.

1527 Wang YJ, Li MD, Wang YM, Chen GZ, Lu GD, Tan ZX. 2000. Effect of extracorporeal

1528 bioartificial liver support system on fulminant hepatic failure rabbits. World Journal of

1529 Gastroenterology 6:252-254. DOI: 10.3748/wjg.v6.i2.252.

1530 Weber LWD, Boll M, Stampfl A. 2003. Hepatotoxicity and Mechanism of Action of

1531 Haloalkanes: Carbon Tetrachloride as a Toxicological Model. Critical Reviews in Toxicology

1532 33:105-136. DOI: $\underline{10.1080 / 713611034 .}$

1533 Welz M, Eickhoff S, Abdullah Z, Trebicka J, Gartlan KH, Spicer JA, Demetris AJ, Akhlaghi

1534 H, Anton M, Manske K, Zehn D, Nieswandt B, Kurts C, Trapani JA, Knolle P, Wohlleber

1535 D, Kastenmüller W. 2018. Perforin inhibition protects from lethal endothelial damage during

1536 fulminant viral hepatitis. Nature Communications 9:4805. DOI: 10.1038/s41467-018-07213-x. 
1537 Wu D, Wang H, Yan W, Chen T, Wang M, Han M, Wu Z, Wang X, Ai G, Xi D, Shen G, Luo

1538 X, Ning Q. 2016. A disparate subset of double-negative T cells contributes to the outcome of

1539 murine fulminant viral hepatitis via effector molecule fibrinogen-like protein 2. Immunologic

1540 Research 64:518-530. DOI: $10.1007 / \mathrm{s} 12026-015-8727-0$.

1541 Yamaguchi Y, Bollinger RR, Defaria E, Landis B, Quarfordt S. 1989. A simplified single stage

1542 total hepatectomy in the rat with maintenance of gastrointestinal absorptive function. Hepatology

1543 9:69-74. DOI: 10.1002/hep.1840090111.

1544 Yang P, Zhou W, Li C, Zhang M, Jiang Y, Jiang R, Ba H, Li C, Wang J, Yin B, Gong F, Li

1545 Z. 2016. Kupffer-cell-expressed transmembrane TNF- $\alpha$ is a major contributor to

1546 lipopolysaccharide and D-galactosamine-induced liver injury. Cell and Tissue Research 363:371-

1547 383. DOI: $10.1007 / \mathrm{s} 00441-015-2252-2$.

1548 Yang T, Mei H, Xu D, Zhou W, Zhu X, Sun L, Huang X, Wang X, Shu T, Liu J, Ding J,

1549 Hassan HM, Zhang L, Jiang Z. 2017. Early indications of ANIT-induced cholestatic liver injury:

1550 Alteration of hepatocyte polarization and bile acid homeostasis. Food and Chemical Toxicology:

1551 An International Journal Published for the British Industrial Biological Research Association

1552 110:1-12. DOI: $10.1016 /$ j.fct.2017.09.051.

1553 Yanguas SC, Cogliati B, Willebrords J, Maes M, Colle I, van den Bossche B, de Oliveira

1554 CPMS, Andraus W, Alves VAF, Leclercq I, Vinken M. 2016. Experimental models of liver

1555 fibrosis. Archives of Toxicology 90:1025-1048. DOI: $\underline{10.1007 / \mathrm{s} 00204-015-1543-4}$.

1556 Yu H, Barrass N, Gales S, Lenz E, Parry T, Powell H, Thurman D, Hutchison M, Wilson ID,

1557 Bi L, Qiao J, Qin Q, Ren J. 2015. Metabolism by conjugation appears to confer resistance to 1558 paracetamol (acetaminophen) hepatotoxicity in the cynomolgus monkey. Xenobiotica 45:2701559 277. DOI: $10.3109 / 00498254.2014 .973000$. 
1560 Yu H, Liu Y, Huang J, Wang H, Yan W, Xi D, Shen G, Luo X, Ning Q. 2017. IL-33 protects

1561 murine viral fulminant hepatitis by targeting coagulation hallmark protein FGL2/fibroleukin

1562 expression. Molecular Immunology 87:171-179. DOI: 10.1016/j.molimm.2017.04.011.

1563 Yu W, Lan X, Cai J, Wang X, Liu X, Ye X, Yang Q, Su Y, Xu B, Chen T, Li L, Sun H. 2020.

1564 Critical role of IL-1 $\beta$ in the pathogenesis of Agrocybe aegerita galectin-induced liver injury

1565 through recruiting $\mathrm{T}$ cell to liver. Biochemical and Biophysical Research Communications

1566 521:449-456. DOI: $10.1016 / \mathrm{j}$. bbrc.2019.10.087.

1567 Yuasa T, Yamamoto T, Rivas-Carrillo JD, Chen Y, Navarro-Alvarez N, Soto-Guiterrez A,

1568 Noguchi H, Matsumoto S, Tanaka N, Kobayashi N. 2008. Laparoscopy-Assisted Creation of a

1569 Liver Failure Model in Pigs. Cell Transplantation 17:187-193. DOI:

$1570 \quad \underline{10.3727 / 000000008783906973}$.

1571 Zhang B-X, Li N, Zhang Z-P, Liu H-B, Zhou R-R, Zhong B-Y, Zou M-X, Dai X-H, Xiao M-

1572 F, Liu X-Q, Fan X-G. 2011. Protective effect of Acanthopanax gracilistylus-extracted

1573 Acankoreanogenin A on mice with fulminant hepatitis. International Immunopharmacology

1574 11:1018-1023. DOI: 10.1016/j.intimp.2011.02.019.

1575 Zhang S, Yang N, Ni S, Li W, Xu L, Dong P, Lu M. 2014. Pretreatment of lipopolysaccharide

1576 (LPS) ameliorates D-GalN/LPS induced acute liver failure through TLR4 signaling pathway.

1577 International Journal of Clinical and Experimental Pathology 7:6626-6634.

1578 Zhang Y, Shi X-L, Han B, Gu J-Y, Chu X-H, Xiao J-Q, Ren H-Z, Tan J-J, Ding Y-T. 2012.

1579 Immunosafety evaluation of a multilayer flat-plate bioartificial liver. The American Journal of the

1580 Medical Sciences 343:429-434. DOI: 10.1097/MAJ.0b013e318232ae0a. 
1581 Zhou P, Xia J, Guo G, Huang Z-X, Lu Q, Li L, Li H-X, Shi Y-J, Bu H. 2012. A Macaca mulatta

1582 model of fulminant hepatic failure. World Journal of Gastroenterology 18:435-444. DOI:

$1583 \quad$ 10.3748/wjg.v18.i5.435.

1584 Zhu C, Sun Y, Luo X, Yan W, Xi D, Ning Q. 2006. Novel mfgl2 Antisense Plasmid Inhibits

1585 Murine fg12 Expression and Ameliorates Murine Hepatitis Virus Type 3-Induced Fulminant

1586 Hepatitis in BALB/cJ Mice. Human Gene Therapy 17:589-600. DOI: 10.1089/hum.2006.17.589. 


\section{Table $\mathbf{1}$ (on next page)}

Table 1. Commonly used preclinical models of acute liver failure. 
Table 1. Commonly used preclinical models of acute liver failure.

\begin{tabular}{|c|c|c|c|c|}
\hline & & Features & Advantages & Disadvantages \\
\hline \multirow[t]{3}{*}{ Surgical } & Anhepatic & $\begin{array}{ll} & \text { Complete removal of } \\
\text { liver } \\
\text { - Single or multi-stage } \\
\text { procedure }\end{array}$ & $\begin{array}{l}\text { - Highly reproducible } \\
\text { - Useful for testing liver } \\
\text { support devices }\end{array}$ & $\begin{array}{ll} & \text { Irreversible } \\
\text { - } & \text { Lacks inflammatory } \\
& \text { response } \\
\text { - } & \text { Technically challenging } \\
\text { in small animals }\end{array}$ \\
\hline & Partial hepatectomy & $\begin{array}{l}\text { - Resection of } 70-97 \% \text { of } \\
\text { liver mass }\end{array}$ & $\begin{array}{l}\text { - Direct clinical correlate } \\
\text { - Useful for studies of } \\
\text { hepatic regeneration }\end{array}$ & $\begin{array}{l}\text { - Does not typically } \\
\text { produce HE } \\
\text { - Specific to post- } \\
\text { hepatectomy liver failure }\end{array}$ \\
\hline & $\begin{array}{l}\text { Hepatic artery ligation \& } \\
\text { portocaval anastomosis }\end{array}$ & $\begin{array}{l}\text { - One- or two-stage } \\
\text { procedure }\end{array}$ & $\begin{array}{l}\text { - Reliably produces } \\
\text { progressive HE \& coma }\end{array}$ & $\begin{array}{ll}\text { - Irreversible } \\
\text { - No direct clinical } \\
\text { correlate }\end{array}$ \\
\hline \multirow[t]{3}{*}{ Pharmacological } & Acetaminophen & $\begin{array}{ll}- & \text { Injury result of toxic } \\
\text { metabolite (i.e. NAPQI) }\end{array}$ & $\begin{array}{l}\text { - } \quad \text { Direct clinical correlate } \\
\text { - } \quad \text { Dose dependent effect }\end{array}$ & $\begin{array}{ll}\text { - } & \text { May require cytochrome } \\
\text { P450 induction or } \\
\text { glutathione depletion } \\
\text { - Ineffective in rats } \\
\text { - Complicated by } \\
\text { methemoglobinemia in } \\
\text { large animal models }\end{array}$ \\
\hline & D-galactosamine & $\begin{array}{l}\text { Depletes uridine, } \\
\text { interfering with RNA } \\
\text { synthesis } \\
\text { Given with or without } \\
\text { lipopolysaccharide }\end{array}$ & $\begin{array}{l}\text { - Demonstrated efficacy in } \\
\text { variety of small \& large } \\
\text { animal models }\end{array}$ & $\begin{array}{l}\text { - No direct clinical } \\
\text { correlate } \\
\text { Different histological } \\
\text { pattern of injury from } \\
\text { most hepatotoxins }\end{array}$ \\
\hline & Carbon tetrachloride & 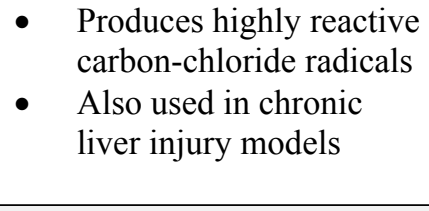 & 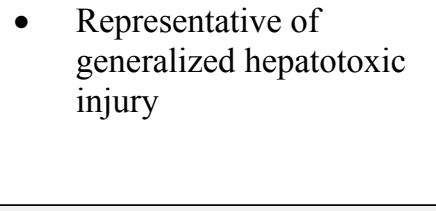 & $\begin{array}{ll}\text { - } & \text { Specific chemical not } \\
\text { encountered clinically } \\
\text { - } & \text { Poor model for HE } \\
\text { - } & \text { Between species } \\
& \text { variability } \\
\end{array}$ \\
\hline \multirow[t]{2}{*}{ Immunogenic } & Concanavalin A & $\begin{array}{l}\text { Immunogenic lectin } \\
\text { derived from jack bean }\end{array}$ & $\begin{array}{l}\text { Representative of T cell } \\
\text { mediated hepatitis, } \\
\text { relevant to autoimmune } \\
\text { hepatitis clinically }\end{array}$ & $\begin{array}{ll}\text { - } & \text { Batch-to-batch } \\
& \text { variability } \\
\text { - } & \text { Species \& strain } \\
\text { differences in } \\
\text { susceptibility }\end{array}$ \\
\hline & Fas antibody & $\begin{array}{l}\text { - Binds \& activates Fas } \\
\text { cell death receptor }\end{array}$ & $\begin{array}{l}\text { - Specifically induces cell } \\
\text { death by apoptosis, an }\end{array}$ & $\begin{array}{l}\text { - Also affects extra- } \\
\text { hepatic tissues (e.g. }\end{array}$ \\
\hline
\end{tabular}




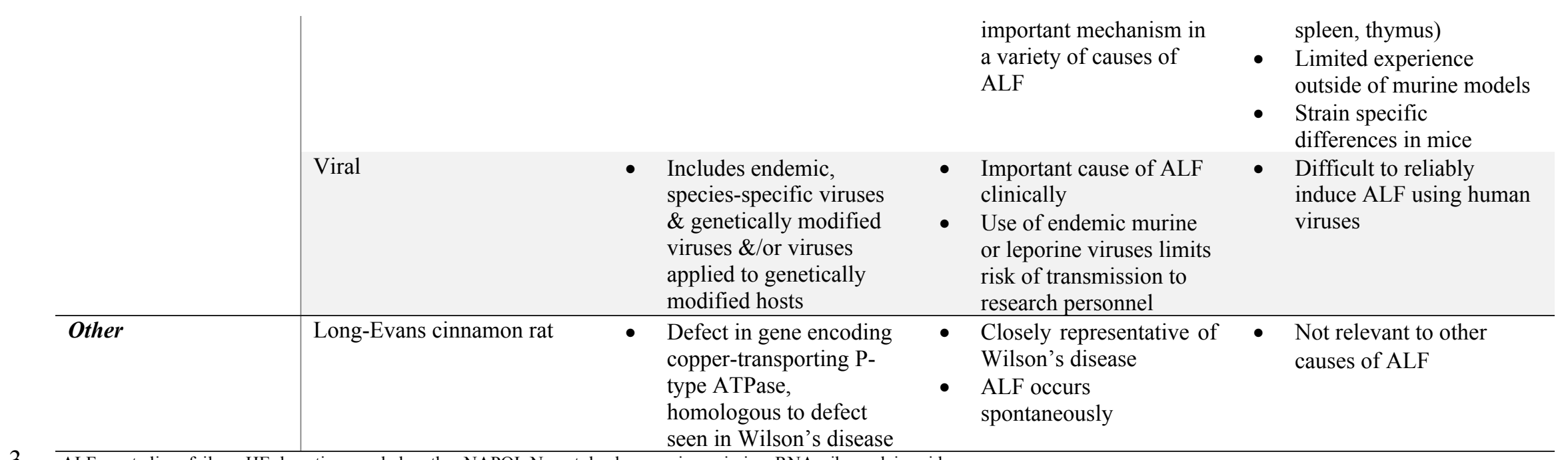


Table 2 (on next page)

Table 2. Pharmacological models of acute liver failure. 
Table 2. Pharmacological models of acute liver failure.

\begin{tabular}{|c|c|c|c|c|c|}
\hline & Structure & Mechanism & $\begin{array}{c}\text { Route of } \\
\text { Administration }\end{array}$ & $\begin{array}{l}\text { Animal } \\
\text { Models }\end{array}$ & Dosage \\
\hline Acetaminophen & & $\begin{array}{l}\text { Alternative metabolism by } \\
\text { cytochrome P450 leads to } \\
\text { production of toxic metabolite } \\
\text { NAPQI }\end{array}$ & PO, SC, IP, IV & $\begin{array}{l}\text { Mouse, } \\
\text { rat*, } \\
\text { rabbit, } \\
\text { dog, pig }\end{array}$ & $\begin{array}{l}200-900 \mathrm{mg} / \mathrm{kg} \\
\text { (mouse) } \dagger\end{array}$ \\
\hline d-Galactosamine & & $\begin{array}{l}\text { Depletion of intracellular uridine } \\
\text { stores necessary for RNA synthesis }\end{array}$ & IP, IV & $\begin{array}{l}\text { Mouse, } \\
\text { rat, rabbit, } \\
\text { dog, pig, } \\
\text { primate }\end{array}$ & $\begin{array}{l}400-1000 \mathrm{mg} / \mathrm{kg} \\
\text { or } 300-700 \mathrm{mg} / \mathrm{kg} \\
\text { with } 0.1 \mathrm{mg} / \mathrm{kg} \\
\text { LPS }\end{array}$ \\
\hline Carbon Tetrachloride & & $\begin{array}{l}\text { Cytochrome } \mathrm{P} 450 \text { metabolism } \\
\text { produces highly reactive } \\
\text { trichloromethyl \& } \\
\text { trichloromethylperoxy radicals }\end{array}$ & PO, IP, IV & $\begin{array}{l}\text { Mouse, } \\
\text { rat, rabbit, } \\
\text { pig }\end{array}$ & $0.5-2.5 \mathrm{~mL} / \mathrm{kg}$ \\
\hline Thioacetamide & & $\begin{array}{l}\text { Metabolism by cytochrome } \mathrm{P} 450 \text { or } \\
\text { FAD-containing monooxygenase } \\
\text { into hepatotoxins TASO \& } \mathrm{TASO}_{2} \text {, } \\
\text { which forms acetylimidolysine } \\
\text { causing their denaturation }\end{array}$ & IPt & Mouse, rat & $\begin{array}{l}200-1600 \mathrm{mg} / \mathrm{kg} \\
\text { (bolus) or } 200- \\
600 \mathrm{mg} / \mathrm{kg} \text { daily } \\
\mathrm{x} 2-4 \mathrm{~d}\end{array}$ \\
\hline Azoxymethane & $\mathrm{CH}$ & $\begin{array}{l}\text { Causes DNA alkylation leading to } \\
\text { tumour formation in models of } \\
\text { colorectal cancer, but mechanism } \\
\text { not well characterized in } \\
\text { hepatotoxic models }\end{array}$ & IP & Mouse & 50 or $100 \mathrm{mg} / \mathrm{kg}$ \\
\hline A-Amanitin & & $\begin{array}{l}\text { Inhibitor of RNA polymerase II, } \\
\text { disproportionately affecting cells } \\
\text { with high metabolism }\end{array}$ & IP & $\begin{array}{l}\text { Mouse, } \\
\text { pig, } \\
\text { primate }\end{array}$ & $\begin{array}{l}0.6 \mathrm{mg} / \mathrm{kg} \text { or } \\
0.1 \mathrm{mg} / \mathrm{kg} \text { with } \\
0.1 \mu \mathrm{g} / \mathrm{kg} \text { LPS }\end{array}$ \\
\hline $\begin{array}{l}\text { A- Naphthyl } \\
\text { Isothiocyanate }\end{array}$ & & $\begin{array}{l}\text { Cholestatic injury caused by } \\
\text { accumulation in cholangiocytes } \\
\text { leads to impaired bile flow \& } \\
\text { eventually hepatocyte necrosis }\end{array}$ & $\mathrm{PO}$ & Mouse, rat & $25-100 \mathrm{mg} / \mathrm{kg}$ \\
\hline
\end{tabular}


5 †repeated or continuous administration often required for large animal models

6 tcan be administered PO, but not typically done with acute models 


\section{Figure 1}

Figure 1. Differences between clinical and preclinical models of acute liver failure.

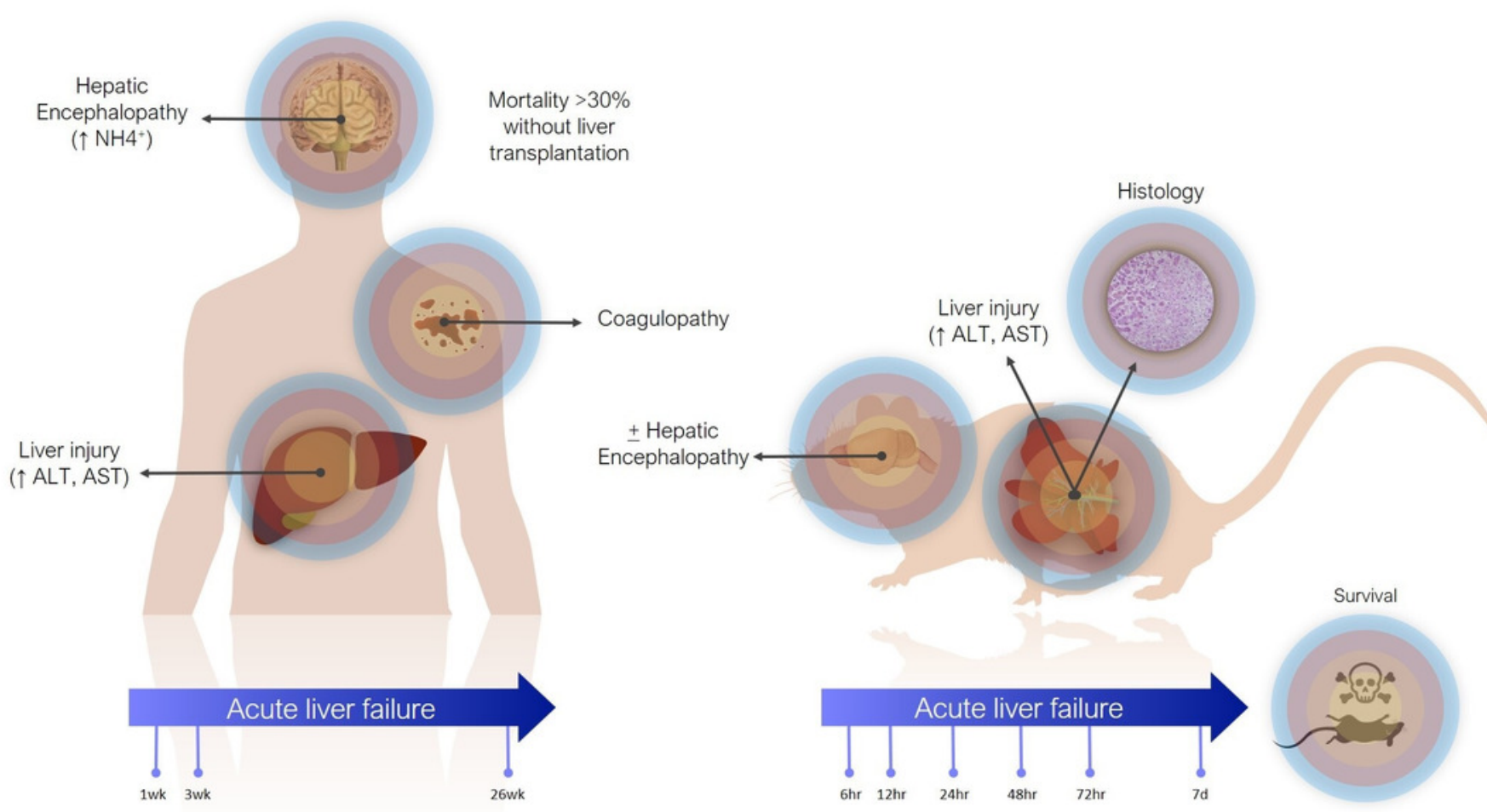


Figure 2

Figure 2. Lobes resected in different murine models of post-hepatectomy liver failure.
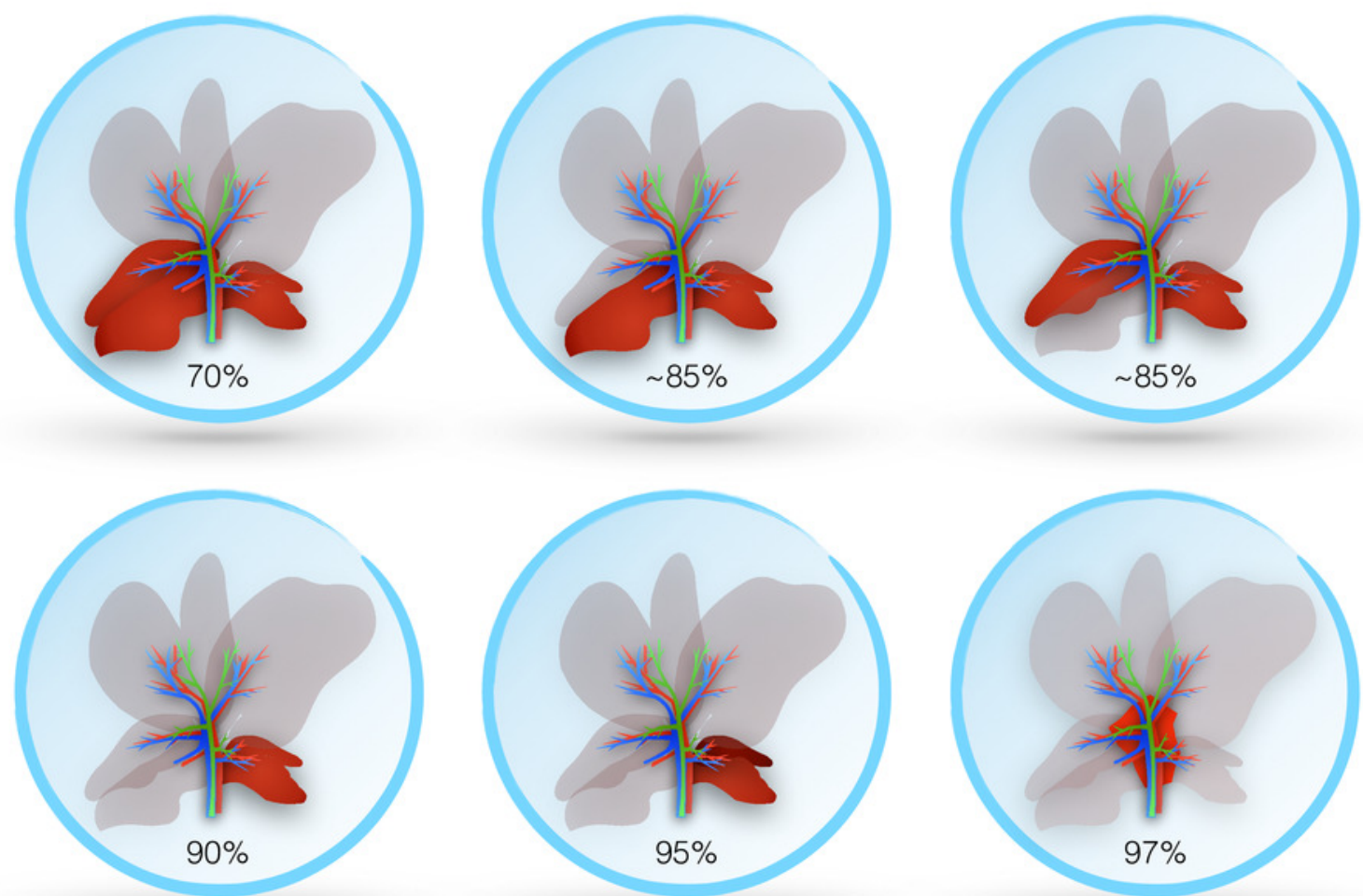
Figure 3

Figure 3. Portocaval anastomosis and hepatic artery ligation as a model of acute liver failure 


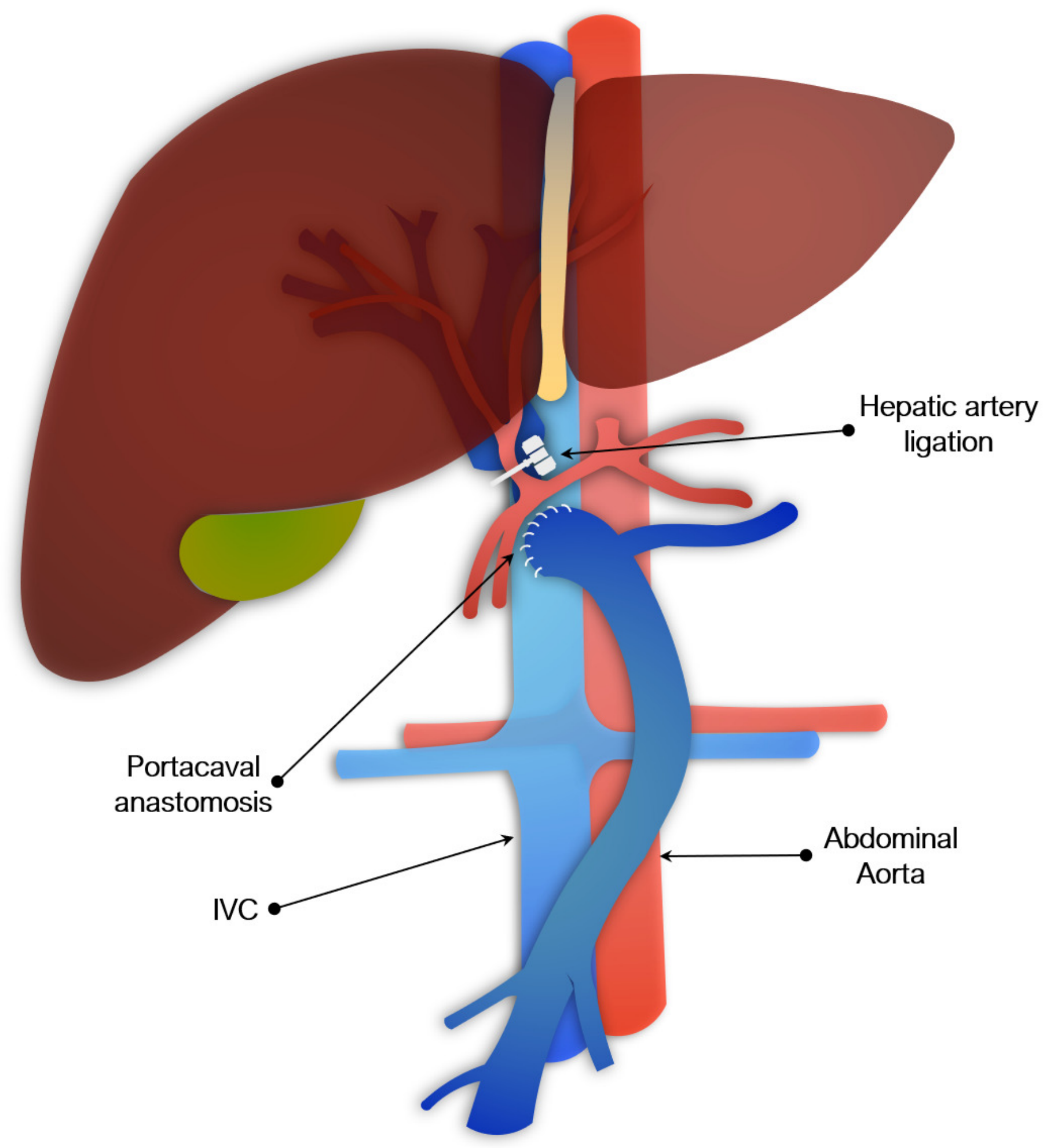

